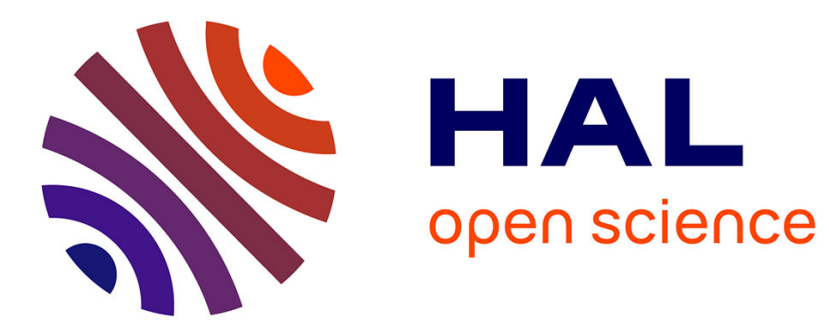

\title{
Plant Names as Traces of the Past in Shuiluo Valley, China
}

Katia Chirkova, Franz K Huber, Caroline S Weckerle, Henriette Daudey, Gerong Pincuo

\section{- To cite this version:}

Katia Chirkova, Franz K Huber, Caroline S Weckerle, Henriette Daudey, Gerong Pincuo. Plant Names as Traces of the Past in Shuiluo Valley, China. Journal of Ethnobiology, 2016, 36 (1), pp.192-214. 10.2993/0278-0771-36.1.192 . hal-01485361

\section{HAL Id: hal-01485361 https://hal.science/hal-01485361}

Submitted on 8 Mar 2017

HAL is a multi-disciplinary open access archive for the deposit and dissemination of scientific research documents, whether they are published or not. The documents may come from teaching and research institutions in France or abroad, or from public or private research centers.
L'archive ouverte pluridisciplinaire HAL, est destinée au dépôt et à la diffusion de documents scientifiques de niveau recherche, publiés ou non, émanant des établissements d'enseignement et de recherche français ou étrangers, des laboratoires publics ou privés. 


\section{Plant Names as Traces of the Past in Shuiluo Valley, China}

Katia Chirkova $^{1 *}$, Franz K. Huber ${ }^{2}$, Caroline S. Weckerle ${ }^{3}$, Henriette Daudey ${ }^{4}$, and Gerong Pincuo 5

${ }^{1}$ Centre National de la Recherche Scientifique (CNRS), Centre de Recherches Linguistiques sur l'Asie Orientale (CRLAO). EHESS-CRLAO, 105 boulevard Raspail, 75006 Paris, France.

${ }^{2}$ ETH Zürich, Institute for Environmental Decisions - Group Society, Environment and Culture.

${ }^{3}$ Institute of Systematic Botany, University of Zürich.

${ }^{4}$ SIL International / Lijiang Teacher's College 丽江师范高等专科学校.

${ }^{5}$ Lijiang Teacher's College 丽江师范高等专科学校.

*Corresponding author (katia.chirkova@gmail.com)

This study presents results of interdisciplinary fieldwork in Southwest China by a team of linguists and ethnobotanists. It is based on a comparative analysis of 70 common plant names in five Tibeto-Burman languages spoken in Shuiluo Valley. The discussion focuses on (a) names for locally important field crops and (b) plant names that are shared between two or more languages. We make a preliminary stratification of cognates and loanwords; we advance hypotheses about the sources of loanwords; and we assess the distribution of loanwords against the background of the existing historical and linguistic accounts of the studied languages. The observed patterns shed light on the 
complex migration history in the area and identify a group of plant names which may originate in a linguistic variety which was once (or still is) native to Shuiluo.

Keywords: plant name, loanword, cognate, language contact, linguistic history, TibetoBurman

本文对中国西南地区的四川省木里藏族自治县水洛乡的五个藏缅语族语言中 70 种 常见植物的名称进行比较研究, 是由一队语言学家和民族植物学家共同参与的跨学 科田野调查的结果。本文讨论集中在：（1）当地主要作物的名称;（2）两种或两 种以上的语言中形式与意义都相同的植物名称。我们对这两类植物名称进行初步的 同源词和借词的划分, 提出一些假设来解释借词的来源, 并结合关于当地族群及其 语言的历史背景情况来分析借词的分布规律。本研究结果不但阐明了水洛河谷地区 复杂的人口迁移历史, 而且辨明了一组当地独特的植物名称一一这些植物名称可能 源自于该地区曾经或者依旧存在的语言。

关键词：植物名称, 借词, 同源词, 语言接触, 语言史, 藏缅语族

\section{Introduction}

Plant names are of great interest for comparative and historical studies of languages, as evidence of both genetic relatedness and past contact between ethnic groups. Plants that are central to the traditional culture of a group, such as crops, tend to 
have names that are cognate (historically related) in related languages. For example, a comparative analysis of crop names, correlated with the history of crop domestication and agricultural development, may yield important clues to the population history of entire regions and to the phylogeny of entire language families (for East Asian languages, see for instance Bellwood 1984-1985; Bradley 2011; Sagart 2003; Sagart et al. 2005).

Plants may also be encountered as novel objects brought in from the outside by trade or by cultural contact, such as Old World crops (wheat, barley, peach) introduced to the Americas, or New World crops (such as maize, common bean, potatoes) introduced to Europe. Names for such novel plants are subject to various naming strategies, including borrowing the original term (thus creating a loan word) or using semantically similar native terms (see for instance Brown [1999] in relation to the incorporation of European words into Amerindian languages). Alternatively, plants may be encountered as novel objects when ethnic groups move into a new area. Together with toponyms and terms for local fauna, terms for local flora are among the first concepts to be taken over by the newcomers (e.g., Schneider 2007:39, 56, 79).

All in all, plant names with similar form and meaning shared by different languages (as cognates or as loanwords) may offer valuable information on the degree of relatedness between these languages, on past contact between the ethnic groups that speak them, and on their migration history. The present paper explores this assumption in relation to names for commonly used plants in five Tibeto-Burman languages spoken in one mountain valley located in the Hengduan (横断) Mountains Region in southwest China. 
The Hengduan Mountains are renowned for their extreme biological, ethnic, and linguistic diversity. The region is one of the hotspots of global biodiversity (Myers et al. 2000; Wang et al. 1995). It is also one of the most ethnically and linguistically complex areas of China, as it served for centuries as a migration corridor for various TibetoBurman groups (e.g., Hsu 1998). The region's remote and mountainous location has thus far been a major obstacle to its exploration. As a result, we know little about the local ethnic groups and their languages, and especially about their complex interaction. This paper addresses these issues by focusing on shared common plant names in the local languages to provide independent insights on the relationships between these languages and their contact history.

\section{The Study Site and Its People}

The study site, Shuiluo Valley (水洛), lies at approximately $28^{\circ} \mathrm{N}$ and $101^{\circ} \mathrm{E}$. It is

located in Shuiluo Township (水洛乡), which is part of Muli Tibetan Autonomous County (Muli Zangzu Zizhixian 木里藏族自治县，Written Tibetan [hereafter WT] smi li rang skyong rdzong) in Sichuan Province (四川省) in the People's Republic of China (Figure 1). ${ }^{1}$

Shuiluo Valley is drained by the Shuiluo River (水洛河), a tributary of the Yangtze (Muli Gazetteers 2010:306). The elevation in the valley ranges from ca. $2200 \mathrm{~m}$ at the valley floor to over $6200 \mathrm{~m}$ at the summits of the surrounding mountains. Local vegetation can be broadly divided into five belts: (a) subtropical shrub vegetation from 
the valley floor to the altitude of $2400 \mathrm{~m}$, (b) pine forest (Pinus yunnanensis Franch.) from 2400 to $2800 \mathrm{~m}$, (c) pine mixed forest from 2800 to $3500 \mathrm{~m}$, (d) conifer mixed forest from 3500 to $4400 \mathrm{~m}$, and (e) alpine shrub forest above 4000 to $4500 \mathrm{~m}$ (Weckerle et al. 2006:5).

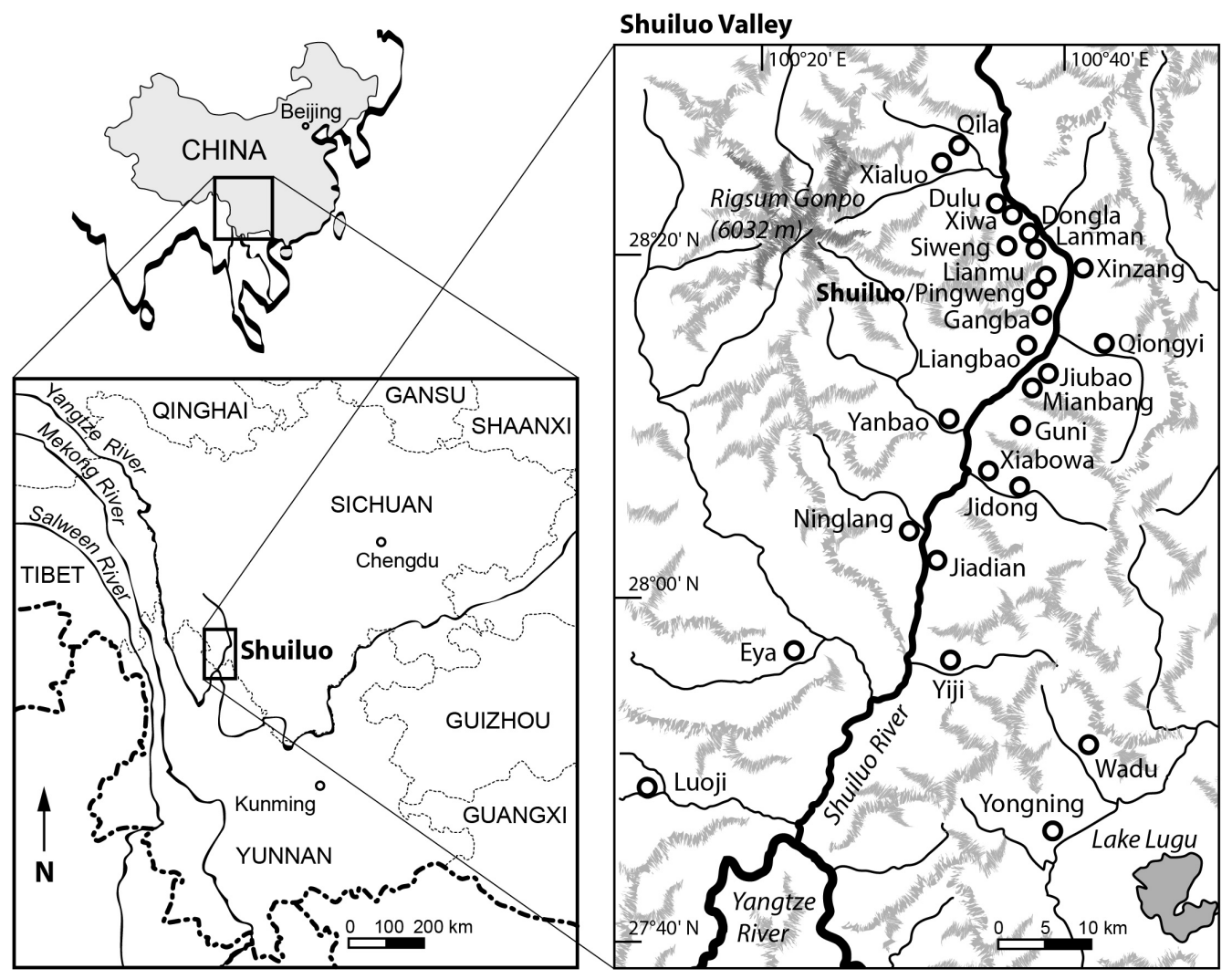

Figure 1. Location of Shuiluo Valley and place names mentioned in the text

There are five local ethnic groups in the study area. These are: ${ }^{2}$

1. Pumi (普米), historically the local ethnic majority, self-designation / $\mathrm{p}^{\mathrm{h}}$ ¿ðốmâ/.

Until recently, the Pumi language served as a local lingua franca. Currently, Mandarin Chinese is replacing the Pumi language in this role. 
2. Tibetans, self-designation /pè/, WT bod. The local name of the group in the national Mandarin Chinese language, Gami (嘎米), stems from Pumi /kámâ/, possibly "helpers" (hereafter Kami).

3. "Shu people," self-designation / ${ }^{\mathrm{EP}} \int \mathrm{t}-\mathrm{h} \tilde{\mathbf{i}} /$ or $/{ }^{\mathrm{EP}} \mathrm{Qu}-\mathrm{h} \tilde{\mathbf{i}} /$. The local name of the group, Xumi (旭米), is also reportedly of Pumi origin, / cùmá/ “Shu people” (hereafter Xumi).

4. “Muli Mongolians,” speakers of the Moxie (摩些) or Mosuo (摩梭) language, self-designation $/ \mathrm{na}^{33} \mathrm{zu}^{33}$ ( (He and Jiang 1985:2) (hereafter Mosuo). The Muli Mongolians see themselves as descendants of Kublai Khan's Mongol army that settled in the area in the thirteenth century.

5. Naxi (纳西), self-designation $/ \mathrm{na}^{31} \mathrm{Gi}^{33} /$ (He and Jiang 1985:2).

Mosuo and Naxi are closely related and collectively known as "Na" people, as they all have /na/ as part of their self-designation (Yang 2006).

With the exception of the Xumi group, which is limited to Shuiluo, all local ethnic groups have a broader distribution beyond Shuiluo Township and the borders of Muli County. Tibetans also live to the north and west of Muli, ${ }^{3}$ the Pumi also live to the north and southwest of Muli, ${ }^{4}$ and the Na groups also live to the southwest of Muli. ${ }^{5}$

The respective cultural and historical centers of these groups lie (a) to the northwest of Muli for Tibetans (the Tibetan Empire, instituted by Srong btsan sgam po in the 
seventh century), (b) to the southwest of Muli for Na groups (the Naxi kingdom in the Lijiang [丽江] area, founded in the mid-thirteenth century), and (c) in Muli and surrounding areas of southwest Sichuan for Pumi (La et al. 2009:27).

Xumi are presently the ethnic majority of Shuiluo Township (with a total of six villages), followed by Kami (with two villages in the upper reaches of the Shuiluo River) and Pumi (with one village in the upper reaches of the Shuiluo River and one village in the middle reaches of the Shuiluo River). Together the three groups account for over $85 \%$ of the population of the township (Muli Gazetteers 2010:28). Mosuo and Naxi, on the other hand, are in the minority. The Mosuo group has one village in the middle reaches of the Shuiluo River, whereas the Naxi group has two villages in the lower reaches of the Shuiluo River.

The settlement in the valley is an outcome of complex migration processes. Pumi are likely to be among the oldest inhabitants of the area. Tibetans, on the other hand, are likely to have arrived in the area around $680 \mathrm{AD}$ following the military and political expansion of the Tibetan empire in the seventh century (Kessler 1986:20). The history and origin of the Xumi group is disputed. Two alternative hypotheses are that the Xumi are among the oldest inhabitants of the area, or that there was a migration to Shuiluo sometime in the Qing (清) dynasty (1644-1911) from the areas to the south of Muli, which was in turn traditionally populated by Na groups (Chirkova 2009:6-7). Xumi have strong links to Na groups and some Naxi historians even consider Xumi as branch of the Na ethnos (Guo and He 1994:8-9; see also Rock 1947:110, footnote 60). Na groups have also been present in Shuiluo throughout its history. Between the fifteenth and the seventeenth centuries, Shuiluo Valley, along with several other valleys which are now 
part of Muli County, were controlled by Naxi Mu (木) kings from their capital in Lijiang (Rock 1947:110,114). The Naxi troops were forced to withdraw only in the early years of the Qing dynasty (Wellens 2010:28). The present-day Naxi and Mosuo inhabitants of Shuiluo Valley, on the other hand, represent recent migrations from the historically Naxi and Mosuo areas to the south of Shuiluo ( Muli Gazetteers 2010:562; essentially Eya, see Figure 1).

Given its location at the intersection of the Tibetan, Na, Xumi, and Pumi groups, ${ }^{6}$ Shuiluo has a long history of multi-ethnicity and relatively equal multilingualism. As a result, the local groups display a high degree of sociocultural and linguistic homogeneity. The local groups also share religious practices, which combine Tibetan Mahayana Buddhism with non-Buddhist religious practices that center on worshipping ancestors and deities (e.g., Oppitz and Hsu 1998; Weckerle et al. 2006; Wellens 2010:119-131, 132158).

The local languages are typologically similar. They are phonologically and morphologically monosyllabic and tonal, with a simple syllable structure (of essentially the type $(\mathrm{C})(\mathrm{C})(\mathrm{G}) \mathrm{V}$, where $\mathrm{C}$ is a consonant, $\mathrm{G}$ is a glide, $\mathrm{V}$ is a vowel nucleus, and brackets indicate optional constituents). They are isolating (weakly agglutinative), and with a basic order SOV with modifier preceding modified.

The precise relationship of most local languages to each other and their broader affiliations within the Tibeto-Burman language family are a matter of dispute. This is not surprising in view of the complex history of the area and the little data that are available on the local languages. Kami is the only language whose genetic position is uncontroversial. It belongs to the Kham dialect of Tibetan of the Bodish subgroup of 
Tibeto-Burman (e.g., Gesang 1964; Qu and Jin 1981). Xumi and Pumi are considered as members of the putative Qiangic subgroup (e.g., Bradley 1997a:35-38; Sun 2001). Naxi and Mosuo (or Na languages) are unclassified and held to be transitional between the Qiangic and Lolo-Burmese subgroups (Bradley 1997a:37). The position of the Xumi language is the least clear of all Shuiluo languages for it has been argued to be more closely related to Na languages than to its putative sister language within the Qiangic subgroup, Pumi (e.g., Chirkova 2009, 2012; Guo and He 1994:8-9).

\section{Data Sources and Methods}

Our study builds on previous ethnobotanical fieldwork in the Shuiluo Valley by Weckerle and Huber between 2004 and 2010 (e.g., Weckerle et al. 2005a, 2005b, 2006). That work includes documentation of plant use by the local groups and the analysis of the traditional knowledge concerning wild collected plant species. It also includes pile sorting and preference ranking tasks for identifying local plant categories (see Weckerle 2005b, 2006).

Data reported in this study were collected in one field trip (of 1 month) to Shuiluo in November 2011. Seventy plant species belonging to 44 families were collected and identified in the field based on plant knowledge from previous fieldwork. The reference herbarium specimens were deposited at the herbarium of the Kunming Institute of Botany (KUN), Chinese Academy of Sciences. All specimens were stored in transparent plastic bags and presented to language consultants as fresh plant material. The collected plants were classified into the following eight categories of use (as based on previous 
ethnobotanical fieldwork): (a) field crops, (b) fruit trees, (c) wild collected food plants, (d) fodder, (e) fuel wood, (f) medicinal plants, (g) ritual plants, and (h) others (Weckerle et al. 2006). A complete list of all collected plants together with their Xumi, Kami, and Pumi meaning equivalents is provided as supplemental material on the Journal's website (https://ethnobiology.org/publications/journal).

We collected linguistic data for each language in different villages (Figure 1; Table 1).

Table 1: Interview locations and number of people interviewed per language

\begin{tabular}{llll}
\hline Language & Village Name & Village Location & $\begin{array}{l}\text { No of people } \\
\text { interviewed }\end{array}$ \\
\hline Xumi & Lanman 兰满 & upper reaches of the Shuiluo River & 3 \\
& Pingweng 平翁 & middle reaches of the Shuiluo River & 2 \\
& Mianbang 免邦 & lower reaches of the Shuiluo River & 2 \\
Kami & Dulu 都鲁 & upper reaches of the Shuiluo River & 1 \\
Pumi & Siweng 四翁 & upper reaches of the Shuiluo River & 1 \\
Mosuo & Lianmu 联木 & middle reaches of the Shuiluo River & 3 \\
Naxi & Jiubao 九保 & lower reaches of the Shuiluo River & 5 \\
\hline
\end{tabular}

The majority of language consultants were middle-aged men, proficient in the contact language, Mandarin, and knowledgeable in plant use. (The male-gender bias is due to the fact that proficiency in Mandarin is low among local farmer women.) Language consultants were asked to name the specimens in the plant collection and instructed to clearly repeat each name three times. For Kami and Pumi, which are 
represented by one consultant each, we additionally cross-checked the collected data against the data collected in previous fieldwork by Weckerle, Huber, and Chirkova, as well as with other informants of these languages interviewed in the administrative seat of Muli County, Qiaowa Town. The collected data were transcribed in the International Phonetic Alphabet (IPA). Kami forms were provided with their Tibetan etymologies (based on regular sound correspondences between Kami and Old Tibetan, as discussed in Chirkova [2014]).

While we used the plant collection to record plant names in all five languages of Shuiluo Valley, further analysis of the collected data was complicated by the fact that the local languages were previously little-documented (or not documented at all, as in the case of the local Mosuo and Naxi varieties) and thus required additional fieldwork and research. Since we were able to collect additional data on the Xumi, Kami, and Pumi languages, these were chosen as the main focus of our analysis. Naxi and Mosuo forms in the main text are cited in phonemic transcriptions if quoted from published sources (for those plants that were previously documented (as in He and Jiang 1985; Huang et al. 1992), and in phonetic transcription if based on firsthand fieldwork.

Our analysis focused, on the one hand, on the names of field crops and, on the other hand, on plant names that are similar in form and meaning in two or more languages throughout the remaining categories of use. The former category of plant names was used as an indication of a relative degree of relatedness between the studied languages. This is because plant names whose use is more universal (such as field crops) are more likely to show widespread cognancy, and, if multiple names are shared, to suggest a close genetic relationship between the languages under investigation (cf. 
Bradley 1997b:161-162). Plant names in the latter category, mostly including plants whose use is less universal, were taken to represent a combination of cognates and loanwords. As the initial step for our comparative analysis of shared plant names, we compiled a list of forms that are similar in form and meaning in (a) Xumi and Kami (a total of eight forms), (b) Xumi and Pumi (five forms), (c) Kami and Pumi (three forms), and (d) the three languages together (nine forms). The resulting list clearly reflected multiple cultural influences and represented a complex combination of (a) loanwords from Tibetan, (b) loanwords from Na languages, (c) loanwords from Pumi, (d) loanwords from Xumi, (e) loanwords from Chinese (yet another dominant regional language), and (f) cognates.

As the second step for each shared form, we attempted to distinguish between these possible sources. Chinese loanwords were few and easy to identify given that the presence of the Han Chinese in the area generally postdates the establishment of Muli County in 1953 (e.g., Li 2010:115-117). Tibetan borrowings in the local languages were more numerous, given that Shuiluo and Muli traditionally fall within the sphere of Tibetan cultural influence. Tibetan was identified as donor for the shared plant name if it had Tibetan etymology. The following sources for Tibetan plant names were used: Hübotter (1957), Gammerman and Semichov (1963), and the Rangjung Yeshe TibetanEnglish Dictionary (2003).

We used a combination of strategies to detect loanwords from $\mathrm{Na}$ languages and Pumi. For those plant names that had been previously documented in other varieties of Na languages (essentially the crop names, as in He and Jiang 1985:141-142; Huang et al. 1992), and in other varieties of Pumi (as in Lu 2001), we were able to compare these 
previously documented forms with our Shuiluo data. If the plant name was shared among different varieties of Na languages, the latter were taken to be the source of the shared forms in the languages of Shuiluo. The same applies to Pumi. In the case of those plant names that had not been previously documented (the majority of forms), we relied on comparative firsthand data from two varieties of Pumi investigated by the authors of the article, the Wadu (瓦都) variety spoken in Ninglang (宁蒗) County, and the Yiji (依吉) variety, spoken in Muli County (to the southeast of Shuiluo Township; Figure 1). Corresponding plant names in these two varieties of Pumi were identified on the basis of Shuiluo Pumi plant data and recorded with three native speakers of Wadu Pumi and two native speakers of Yiji Pumi (all middle-aged men). The basic reasoning was again as follows: if a particular plant name was shared in Shuiluo, Wadu, and Yiji varieties of Pumi, Pumi was taken to be a possible source for the shared plant name in the Shuiluo languages.

As the final step of our analysis, we examined the distribution of plant names with similar form and meaning in relation to their categories of use. We then assessed the resulting patterns against the background of the existing historical and linguistic accounts of the Xumi, Kami, and Pumi languages as outlined above.

The proposed analysis is admittedly tentative. All local languages are unwritten, spoken in a multilingual setting, and little-documented. Both our documentary record and the historical data are sketchy, if not entirely absent, and the preliminary state of research on the languages precludes a systematic investigation of the layering of lexical material (e.g., as discussed in Andersen 2003; Sagart and Xu 2001). In addition, the overall number of plant names shared between any two given languages is insufficient to 
exhaustively address the issue of regular sound correspondences between them.

Nonetheless, despite the preliminary nature of our findings, our study has the potential to contribute to the furthering of our understanding of the linguistic history of Shuiluo as it provides (a) new data for future, more systematic historical-comparative studies of the local languages based on a larger body of evidence, and (b) independent support for the existing historical and linguistic accounts of the local languages.

\section{Results}

\section{Field Crops}

The field crops discussed in this section represent the core cultigens of the local ethnic groups and account for the major portions of their diet. They include (a) species of native origin and of early introduction (Table 2) and (b) species that were introduced

more recently (Table 3). ${ }^{7}$ Given that Na languages are conventionally held to be transitional between the Qiangic and Lolo-Burmese subgroups, sharing lexical material with both subgroups (Bradley 1997a:37), Table 2 also includes reconstructed LoloBurmese forms from Bradley (1997b, 2011). 
Table 2: Names for field crops of native origin or early introduction in Shuiluo languages ${ }^{8}$

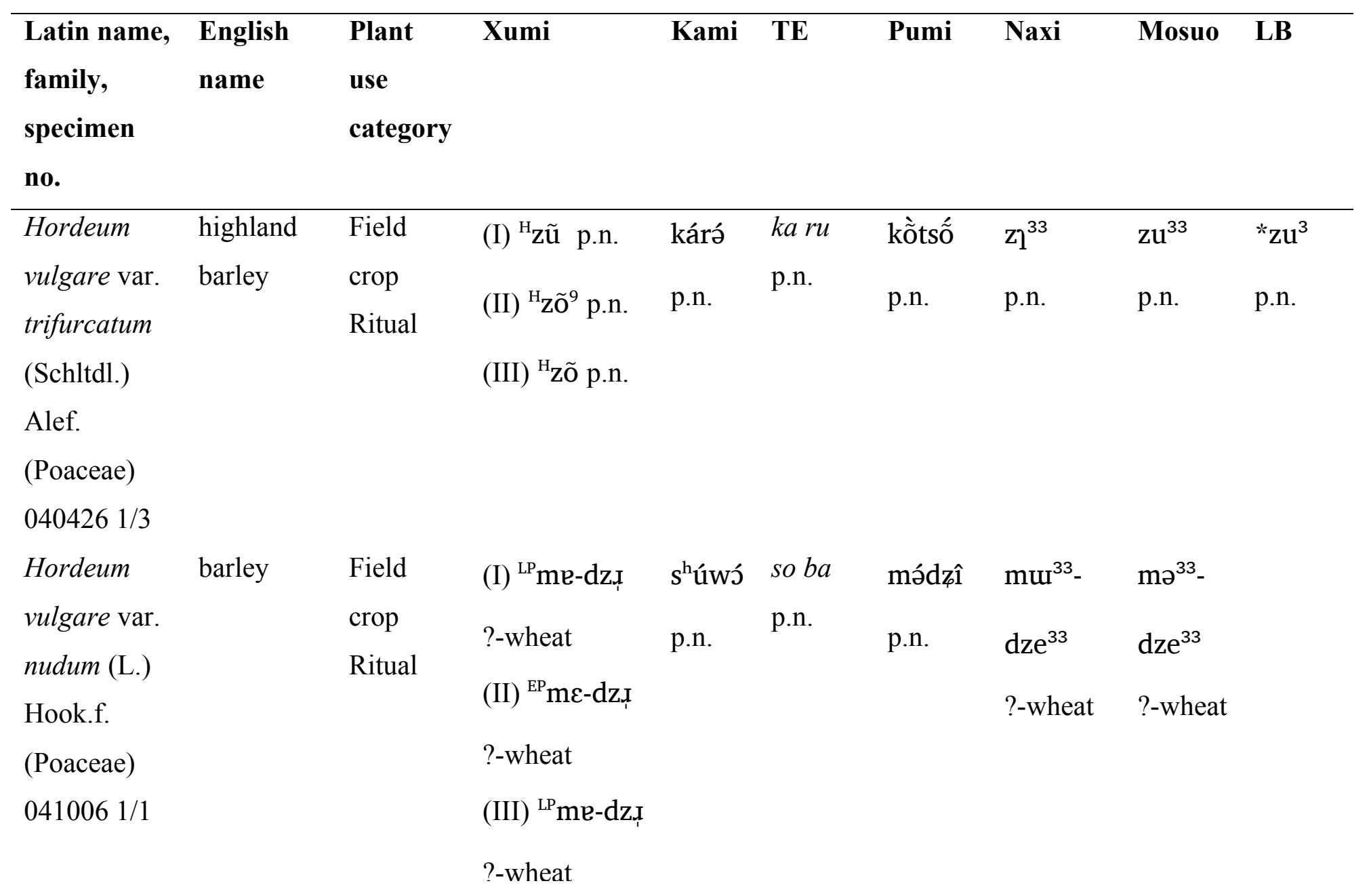




\begin{tabular}{|c|c|c|c|c|c|c|c|c|c|}
\hline $\begin{array}{l}\text { Latin name, } \\
\text { family, } \\
\text { specimen } \\
\text { no. }\end{array}$ & $\begin{array}{l}\text { English } \\
\text { name }\end{array}$ & $\begin{array}{l}\text { Plant } \\
\text { use } \\
\text { category }\end{array}$ & Xumi & Kami & TE & Pumi & Naxi & Mosuo & LB \\
\hline $\begin{array}{l}\text { Triticum } \\
\text { aestivum L. } \\
\text { (Poaceae) } \\
0404261 / 4\end{array}$ & wheat & $\begin{array}{l}\text { Field } \\
\text { crop } \\
\text { Ritual }\end{array}$ & $\begin{array}{l}\text { (I) }{ }^{\mathrm{H}} \mathrm{dzd} \text { p.n. } \\
\text { (II) }{ }^{\mathrm{H}} \mathrm{dzI} \text { p.n. } \\
\text { (III) }{ }^{\mathrm{H}} \mathrm{dzI} \text { p.n. }\end{array}$ & $\begin{array}{l}\text { tşù } \\
\text { p.n. }\end{array}$ & $\begin{array}{l}\text { gro } \\
\text { p.n. }\end{array}$ & $\begin{array}{l}\hat{\mathrm{e}} \\
\text { p.n. }\end{array}$ & $\begin{array}{l}\mathrm{dze}^{33} \\
\text { p.n. }\end{array}$ & $\begin{array}{l}\mathrm{dze}^{33} \\
\text { p.n. }\end{array}$ & $\begin{array}{l}* \mathrm{ša}^{3} \\
\text { p.n. }\end{array}$ \\
\hline $\begin{array}{l}\text { Oryza sativa } \\
\text { L. } \\
\text { (Poaceae) }\end{array}$ & $\begin{array}{l}\text { husked } \\
\text { rice }\end{array}$ & $\begin{array}{l}\text { Field } \\
\text { crop } \\
\text { Ritual }\end{array}$ & $\begin{array}{l}\text { (I) }{ }^{\mathrm{LP}} \mathrm{t} \epsilon^{\mathrm{h}} \varepsilon \mathrm{cme} \\
\text { p.n. } \\
\text { (II) }{ }^{\mathrm{EP}} \mathrm{t} \epsilon^{\mathrm{h}} \varepsilon \mathrm{Ee} \\
\text { p.n. } \\
\text { (III) }{ }^{\mathrm{LP}} \mathrm{t} \varphi^{\mathrm{h}} \mathrm{eme}\end{array}$ & $\begin{array}{l}\text { Ndzé } \\
\text { p.n. }\end{array}$ & $\begin{array}{l}\text { 'bras } \\
\text { p.n. }\end{array}$ & $\begin{array}{l}\mathrm{t} \varphi^{\mathrm{h}} \mathrm{we \check { }} \\
\text { p.n. }\end{array}$ & $\begin{array}{l}\mathrm{ts}^{\mathrm{h}} \mathrm{ua}^{33} \\
\text { p.n. }\end{array}$ & $\begin{array}{l}\mathrm{t}^{\mathrm{h}} \mathrm{ye}^{33} \\
\text { p.n. }\end{array}$ & $\begin{array}{l}\text { *čan }{ }^{1} \\
\text { p.n. }\end{array}$ \\
\hline
\end{tabular}




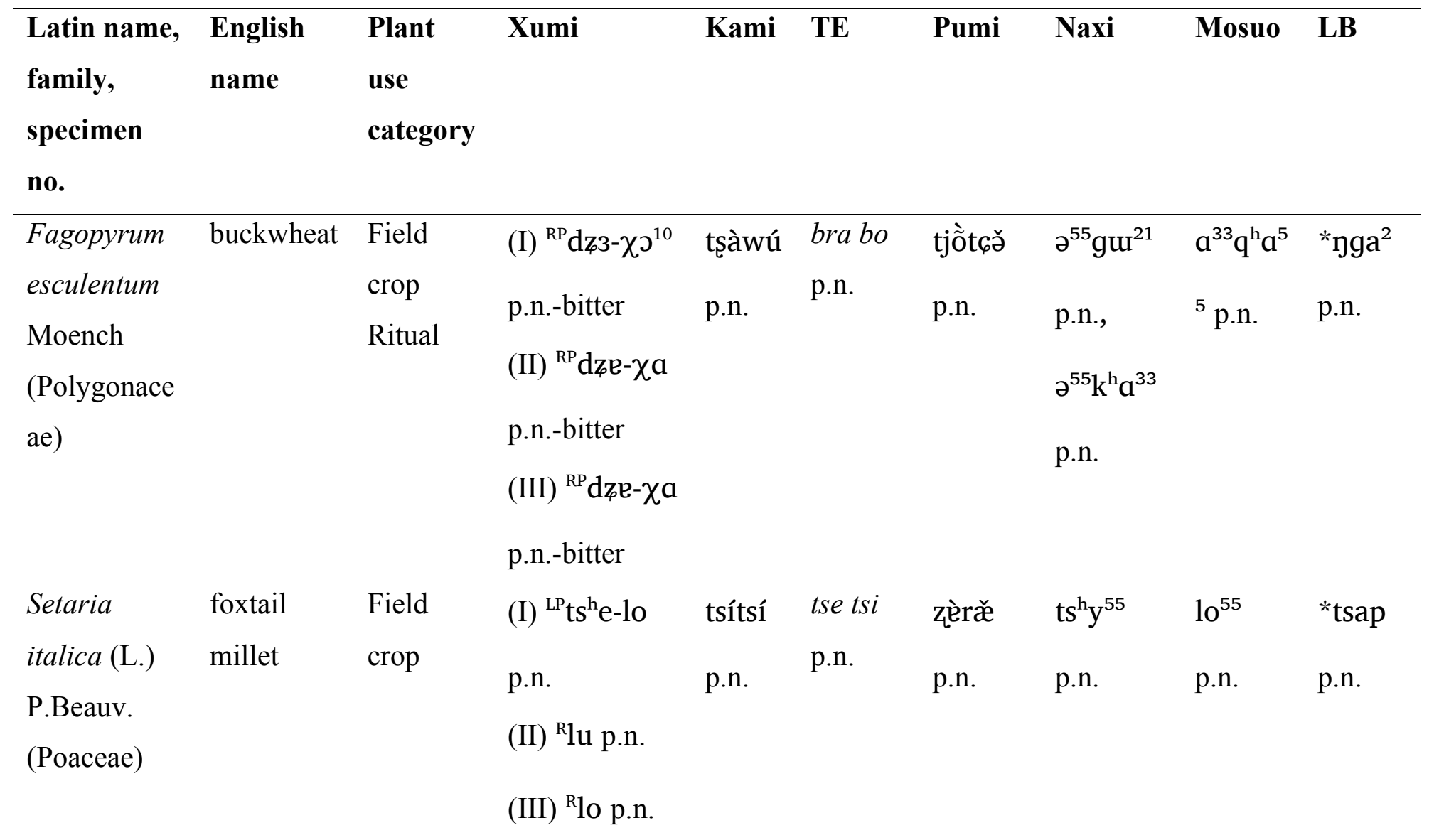




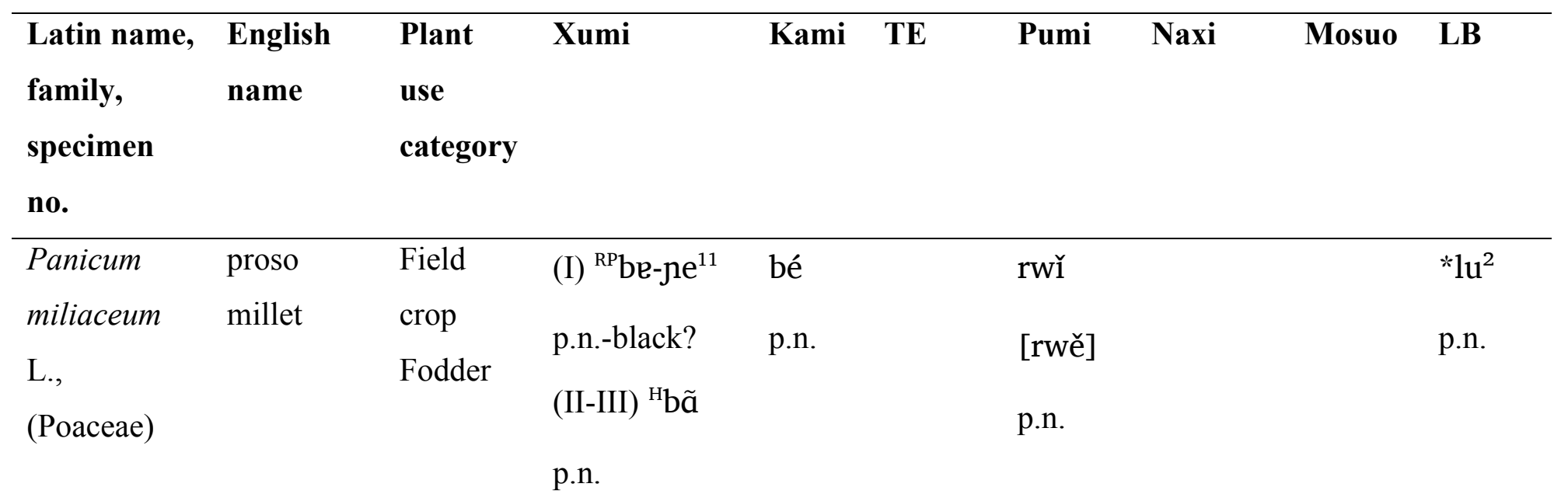




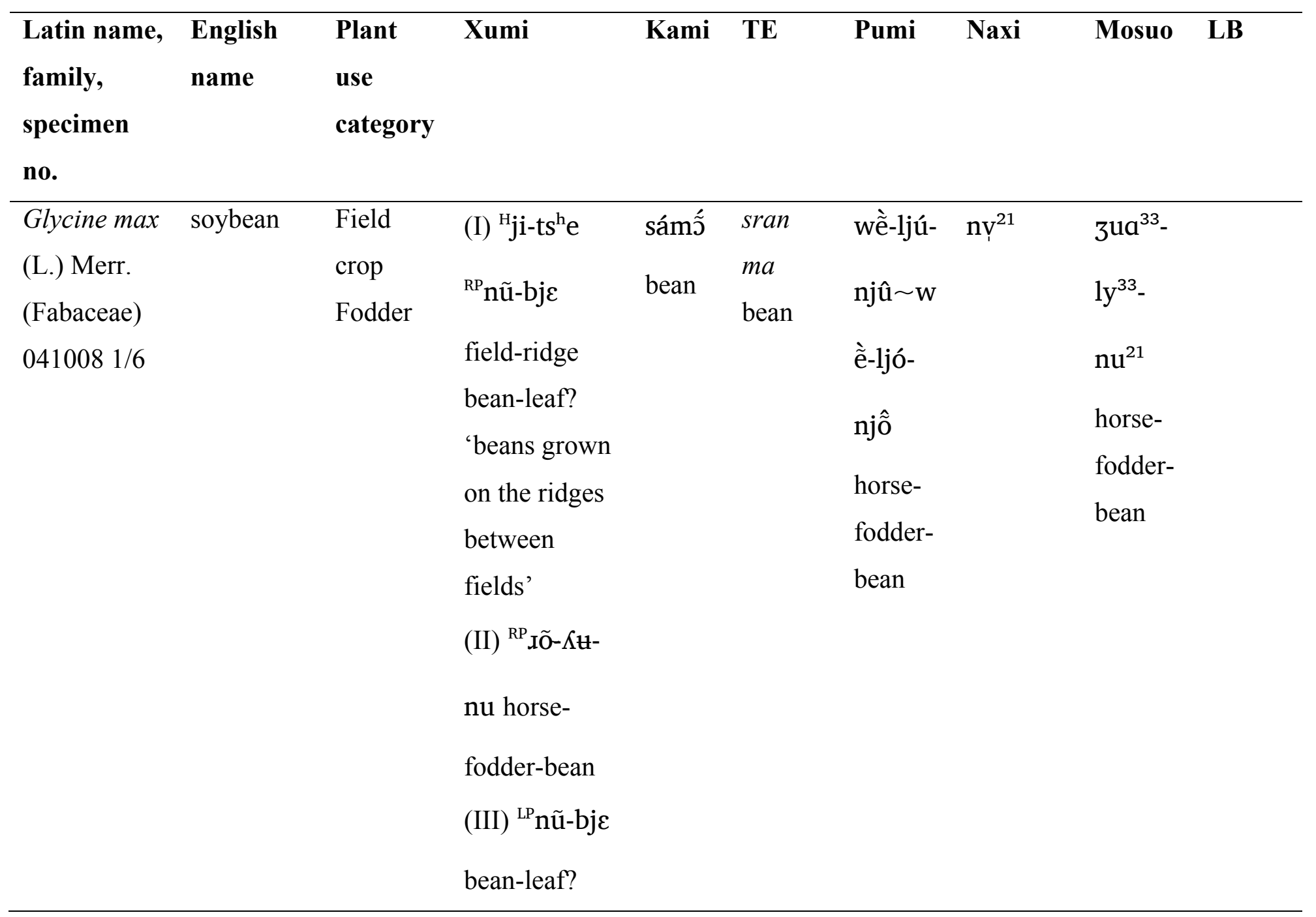


The names for the field crops suggest several things about the five languages.

First, Kami has the most transparent set of names for field crops of all Shuiluo languages, for all Kami field crop names have clear Tibetan etymologies. Second, consistent with the idea that Xumi may be closely related to Na languages and that Na languages share much lexical material with Lolo-Burmese languages, most Xumi field crop names appear cognate to Naxi and Mosuo field crop names, and some forms may be relatable to the Burmic stock (such as those for "highland barley" [Hordeum vulgare L. var. trifurcatum] or "rice" [Oryza sativa L.]). Third, Pumi field crop names are mostly distinct from Kami, Xumi, Naxi and Mosuo forms. Three forms are shared between Shuiluo Pumi, Xumi, Naxi, and Mosuo: (a) "barley" (Hordeum vulgare L. var. nudum), (b) "rice" (possibly relatable to the Lolo-Burmese etymon *čan ${ }^{1}$ ), and (c) the base element in "soybean" (Glycine max [L.] Merr.) (Xumi / ${ }^{R}$ ñ̃/ or $/{ }^{R}$ nõ/, Naxi $/ \mathrm{nv}^{21} /$, Mosuo $/ \mathrm{nu}^{21} /$, Pumi /njû/ or /njô/, relatable to Proto-Tibeto-Burman *nok, *s-nok, or *s-nuk [Matisoff 2003:39, $605])$.

Finally, we note that names for "wheat" (Triticum aestivum L.) and "barley" in Xumi, Naxi, and Mosuo share the base element "wheat" (Xumi $/{ }^{\mathrm{H}} \mathrm{dzx} /$, Naxi and Lianmu Mosuo $\left./ \mathrm{dze}^{33} /\right)$. Names for "barley" in these languages combine this base element with a modifier element of unknown etymology (Xumi ${ }^{L \mathrm{LP}} \mathrm{me}-\mathrm{dzd} /$ or $/{ }^{\mathrm{EP}} \mathrm{me}$-dzul, Naxi $/ \mathrm{mu}^{33}$ $\mathrm{dze}^{33} /$, Lianmu Mosuo $/ \mathrm{m}^{33}$-dze $\left.\mathrm{di}^{33}\right)$. By contrast, in the name for "barley" in Shuiluo 
Pumi (/mádzîl), which is similar to Xumi, Naxi, and Lianmu Mosuo forms, there appears to be no connection between the element /dŷi/ in second-syllable position and the native

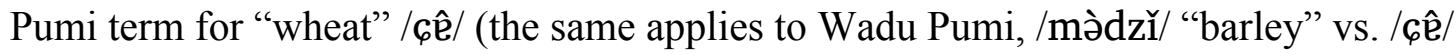
"wheat"). This suggests that the Pumi name for "barley" is a loanword from $\mathrm{Na}$ languages, rather than a native Pumi word.

Table 3 lists names for maize (Zea mays L.) and common bean (Phaseolus vulgaris L.), two New World crops which were introduced into the area sometime during the last 500 years (see Ho [1955] in relation to maize). The two species are traditionally grown together in Shuiluo, as they are in the Americas, and they probably arrived in China together. Consistent with cross-language naming tendencies for items of acculturation (e.g., Atran 1998; Berlin et al. 1974:53; Brown 1999:50-54, 159-160), native terms for these plants were coined through extending to them the application of the native labels for their closest local analogs: "wheat" in the case of "maize" and "soybean" in the case of "common bean".

The term for "maize" in many languages of China is a compound that contains the "wheat" etymon. To give an example, one of the first Chinese names for "maize" was “foreign wheat”, fanmai (番麦); which was later replaced by “jade wheat,” yumai (玉麦) (Warman 2003:39-40). The use of the "wheat" etymon in the name for "maize" is also common in many Tibeto-Burman languages (e.g., Bradley [1997b] for Lolo-Burmese). Shuiluo languages may be no exception to this pattern. 
Table 3: Names for 'maize' and 'common bean' in Shuiluo languages

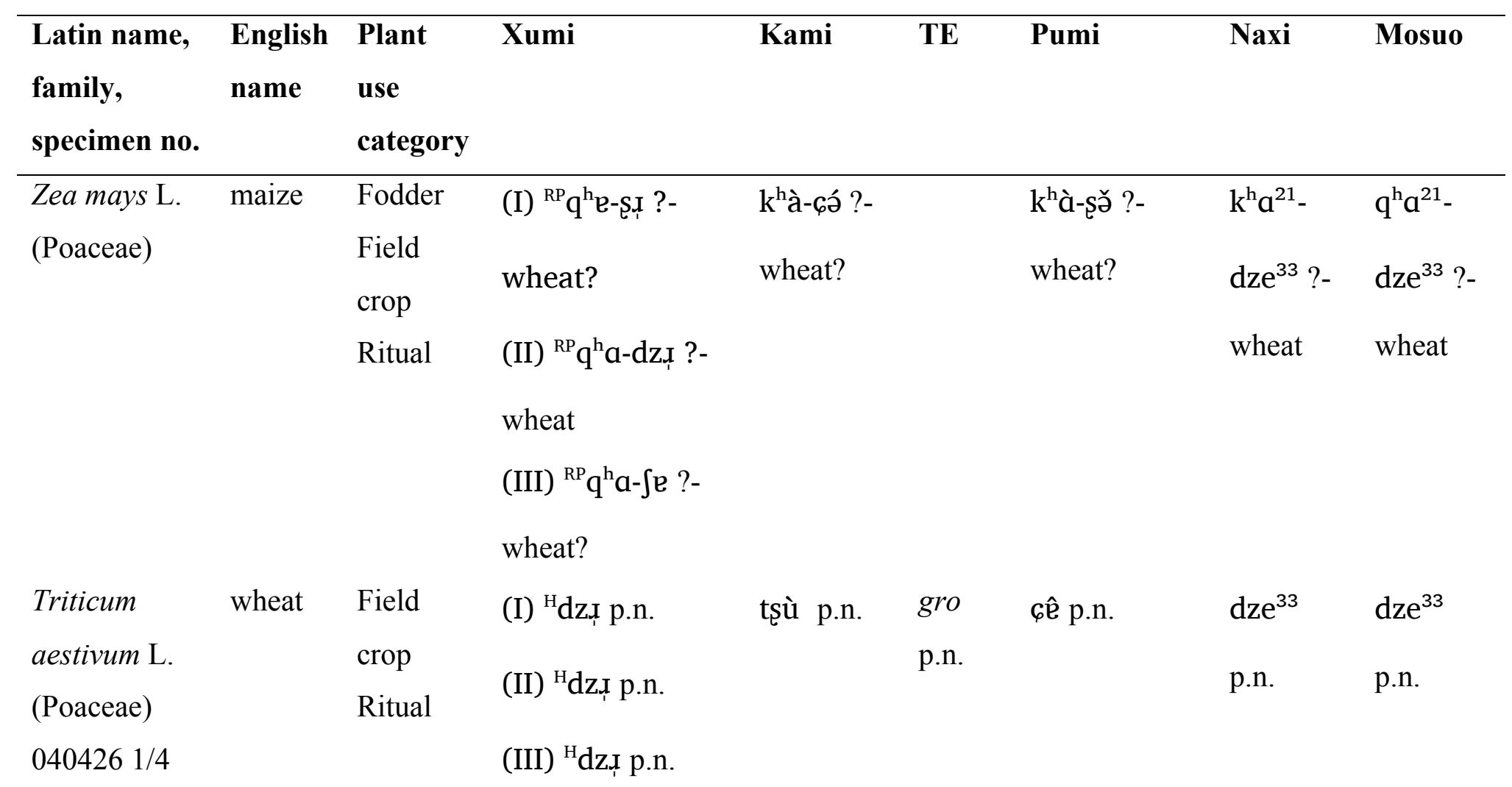




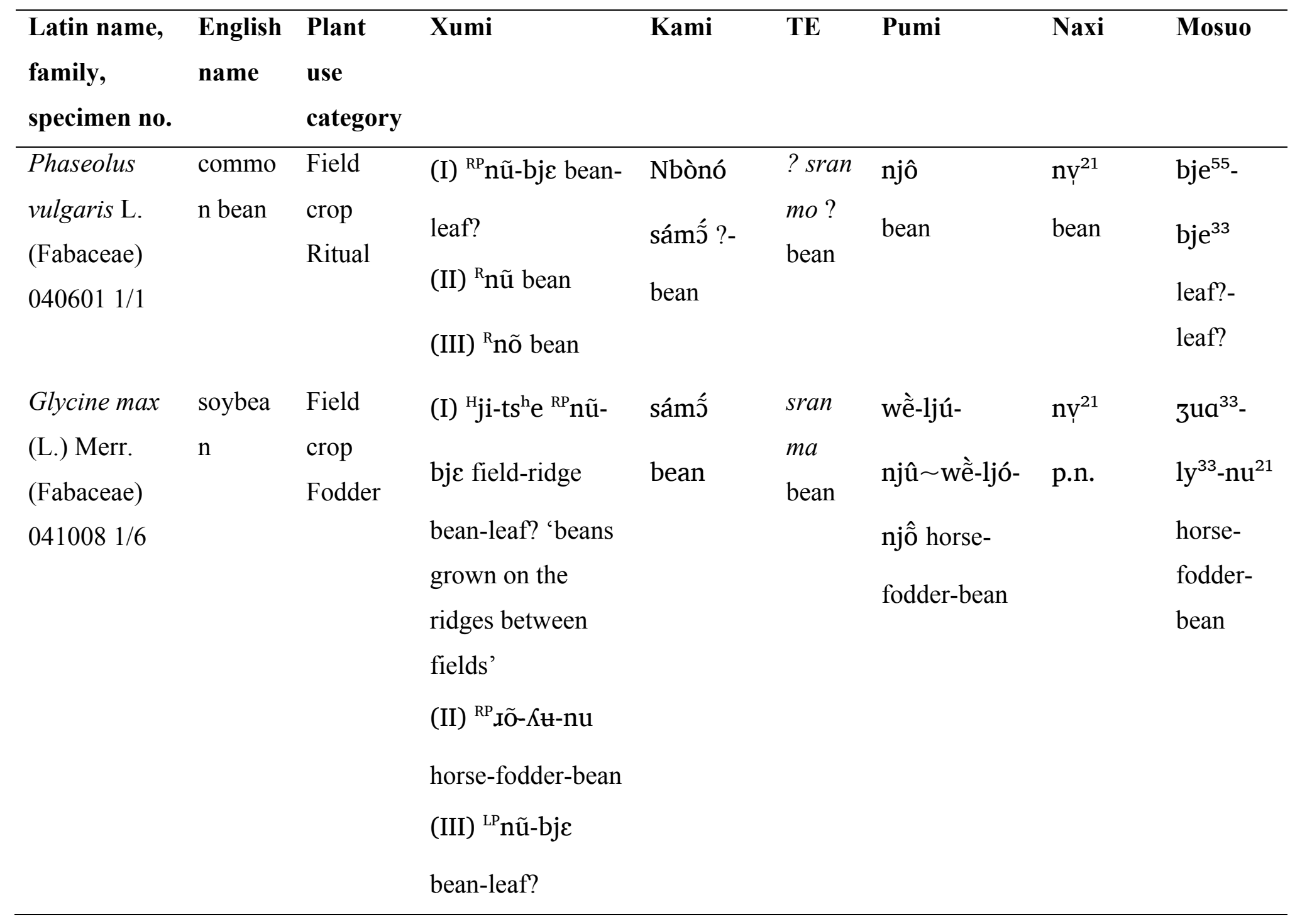


The names for "maize" in Shuiluo languages are all disyllabic forms. In Middle Xumi, Naxi, and Mosuo, they combine a base element with the meaning "wheat" (Xumi $/{ }^{\mathrm{H}} \mathrm{dzd} /$, Naxi and Mosuo $\left./ \mathrm{dze}^{33} /\right)$ with a modifier element of unknown etymology $\left(/ \mathrm{k}^{\mathrm{h}} \mathrm{a} /\right.$ or $/ \mathrm{q}^{\mathrm{h}} \mathrm{a} /$ with a low tone). The similarity of the name for "maize" in Middle Xumi to that in Lianmu Mosuo vis-à-vis different names for "maize" in Upper and Lower Xumi is likely due to the close contact between Middle Xumi and Lianmu Mosuo. The word for "maize" in Middle Xumi is therefore likely a loanword from Mosuo.

In the remaining languages, the same modifier element of unknown etymology $\left(/ \mathrm{k}^{\mathrm{h}} \mathrm{a} /\right.$ or $/ \mathrm{q}^{\mathrm{h}} \mathrm{a} /$ with a low tone) is combined with the element $/ \mathrm{s} . \mathrm{I} /, / \mathrm{s} \partial /, / \mathrm{S} \mathbf{e} /$, or $/ \mathrm{G} ə /$ in secondsyllable position. Given the strong tendency for disyllabic forms for "maize" to contain the "wheat" etymon, we tentatively analyze this element as "wheat," possibly relatable to Burmic *ša ${ }^{3}$ (Bradley 2011:137). We note that in Lower Xumi, Shuiluo Pumi, and Kami, there is no direct connection between that second-syllable element and native words for "wheat." This suggests a possibly external source for the term "maize" in these languages.

Dialectal Pumi data at our disposal provides an interesting perspective to the distribution of the name $/ \mathrm{k}^{\mathrm{h}}$ aş/ (or variants) "maize" in the area. The form $/ \mathrm{k}^{\mathrm{h}} \mathrm{Aş \partial /}$ (with various surface tones) is shared by many northern varieties of Pumi (e.g., Taoba [桃巴], Tuoqi [ 拖七], Zuosuo [左所]). Southern varieties of Pumi (e.g., Lanping [兰坪], Weixi [维西]), 
on the other hand, have different names for this plant: $/ \mathrm{S}^{13} \mathrm{~S}^{55}$ ( (Qinghua [箐花]), $/ \mathrm{SA}^{13} \mathrm{~S}^{55}{ }^{55}$ (Ludian [鲁甸]), / $\mathrm{SA}^{13} \mathrm{t}^{\mathrm{h}} \mathrm{u}^{55}$ / (Xinyingpan [新营盘]) (Lu 2001:378-379). ${ }^{12}$ Alternatively, southern Pumi varieties use a loanword from Naxi (as in Wadu Pumi, $/ q^{\mathrm{h}} \grave{æ}-\mathrm{dzi} /$ ). This suggests one common source for the term "maize" in Muli and surrounding areas. Furthermore, the distribution of the name "maize" in different Pumi varieties also points to a split between northern and southern Pumi varieties before maize was introduced into the area. This correlates well with the historical account that links the split of Pumi into the Northern and Southern dialects to the southwards movement of the Pumi group from their historical area of residence in southwestern Sichuan into Yunnan, which started in the Yuan (元) dynasty (1279-1368), and set forth in the Ming ([明], 1368-1644) and Qing ([清], 1644-1911) dynasties (La et al. 2009:28).

In the case of "common bean," names for this species in most local languages are monosyllabic forms (e.g., Xumi $/^{R} n \tilde{u} /$ or $/{ }^{R} n o ̃ /, ~ N a x i ~ / n v^{21} /$, Mosuo $/ \mathrm{nu}^{21} /$, Pumi /njû/ or

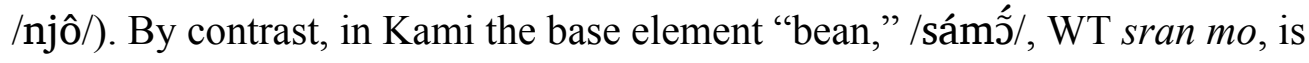
etymologically distinct and preceded by a modifier of unclear origin, /Nbònó/. Furthermore, monosyllabic names for "common bean" in Xumi, Pumi, and Mosuo are used as base element in polysyllabic names for "soybean," an indigenous species, domesticated in the late second millennium BCE in North China (Ho 1975:76-81). That base element in names for "soybean" is preceded by modifier elements ("horse-fodderbean" in most languages). This naming strategy ("overt marking" [Brown 1999:28]) 
stands in clear contrast to that in the case of "maize," in which a monosyllabic name for a local species ("wheat") is used as base element in the disyllabic, descriptive name for a newly introduced species ("maize") (the same strategy can be observed in Kami names for "soybean" and "common bean"). The reverse strategy ("marking reversal" [Brown 1999: 28]) in the case of "common bean" in Xumi, Pumi, and Lianmu Mosuo is likely to reflect the fact that the newly introduced species surpassed the indigenous species in salience (see Brown 1999:139-140, 159): common beans are primarily used by these groups for food, whereas soybeans are primarily used for fodder.

Using names for the field crops of native origin as an indication of the relative degree of relatedness of the local languages, we can observe that (a) Kami is most distantly related to all other Shuiluo languages, (b) Xumi is likely to be closely related to $\mathrm{Na}$ languages, and (c) Pumi is relatively distant from both Xumi and Na languages, for its names for field crops are mostly distinct from those in the latter languages, with only three forms out of eight showing similarity in form and meaning (including one form, "barley," likely being a loanword). Names for "maize" in the local languages reflect, on the one hand, the importance of $\mathrm{Na}$ languages as a source of loanwords in the area to the southwest of Shuiluo (as in Wadu Pumi) and, on the other hand, the importance of a local linguistic variety (which is associated with Muli and surrounding areas) as a source of loanwords in most Shuiluo languages. 
Table 4: Plant names shared between Xumi and Kami (shared forms marked in bold)

\begin{tabular}{|c|c|c|c|c|c|}
\hline $\begin{array}{l}\text { Latin name, family, } \\
\text { specimen no. }\end{array}$ & English name & $\begin{array}{l}\text { Plant use } \\
\text { category }\end{array}$ & Xumi & Kami & TE \\
\hline $\begin{array}{l}\text { Punica granatum L. } \\
0405243 / 1\end{array}$ & pomegranate & $\begin{array}{l}\text { Fruit } \\
\text { Ritual }\end{array}$ & (I-III) ${ }^{\mathrm{RP}}$ semi p.n. & $\begin{array}{l}\text { sèmí } \\
\text { p.n. }\end{array}$ & bse ma p.n. \\
\hline $\begin{array}{l}\text { Pteridium aquilinum } \\
\text { (L.) Kuhn } \\
0405131 / 3\end{array}$ & $\begin{array}{l}\text { common } \\
\text { bracken, eagle } \\
\text { fern }\end{array}$ & $\begin{array}{l}\text { Wild food } \\
\text { Other }\end{array}$ & $\begin{array}{l}\text { (I) }{ }^{\text {LPdeje p.n., }} \\
{ }^{\mathbf{R P}} \text { eygə p.n. }\end{array}$ & $\begin{array}{l}\text { àygə́ } \\
\text { p.n. }\end{array}$ & \\
\hline & & & $\begin{array}{l}\text { (II) }{ }^{\mathrm{EP}} \mathrm{dj} \varepsilon \mathrm{\varepsilon} \varepsilon \text { p.n., }{ }^{\mathrm{R}} \mathrm{dj} \varepsilon \\
\text { p.n. } \\
\text { (III) }{ }^{\mathrm{H}} \mathrm{dj} \varepsilon \text { p.n. }\end{array}$ & & \\
\hline $\begin{array}{l}\text { Acorus calamus L. } \\
040612 \text { 1/1; } 0410101 / 1\end{array}$ & $\begin{array}{l}\text { sweet flag, } \\
\text { calamus }\end{array}$ & Medicinal & $\begin{array}{l}\text { (I-II) }{ }^{{ }^{\mathrm{P}} \mathbf{t} \boldsymbol{\varphi}^{\mathrm{h}} \mathbf{e t e} \text { p.n. }} \\
\text { (III) }{ }^{\mathrm{EP}} \text { tcete p.n. }\end{array}$ & $\begin{array}{l}\text { tc }{ }^{\text {hìtá }} \\
\text { p.n. }\end{array}$ & \\
\hline
\end{tabular}




\begin{tabular}{|c|c|c|c|c|c|}
\hline $\begin{array}{l}\text { Latin name, family, } \\
\text { specimen no. }\end{array}$ & English name & $\begin{array}{l}\text { Plant use } \\
\text { category }\end{array}$ & Xumi & Kami & TE \\
\hline $\begin{array}{l}\text { Prinsepia utilis Royle } \\
040421 \text { 2/1 }\end{array}$ & & $\begin{array}{l}\text { Medicinal } \\
\text { Ritual } \\
\text { Other }\end{array}$ & $\begin{array}{l}\text { (I) }{ }^{\mathrm{LP}} \text { S.I de-ts }{ }^{\mathrm{h}} \text { eke } \\
\text { p.n.? thorn } \\
\text { (II) }{ }^{\mathrm{RP}} \text { dzw3mi- } \\
\text { ts }{ }^{\mathrm{h}} \text { eke sparrow- } \\
\text { thorn } \\
\text { (III) }{ }^{\mathrm{RP}} \text { bewũ -tseke } \\
\text { p.n.? thorn }\end{array}$ & $\begin{array}{l}\text { Jwídà } \\
\text { p.n. }\end{array}$ & \\
\hline $\begin{array}{l}\text { Cornus oblonga Wall. } \\
040419 \text { 1/1; } 040523 \\
2 / 1 ; 0406113 / 2\end{array}$ & & Ritual & $\begin{array}{l}\text { (I-II) }{ }^{\mathrm{RP}} \text { Goke p.n. } \\
\text { (III) }{ }^{\mathrm{RP}} \text { coka p.n. }\end{array}$ & $\begin{array}{l}\text { còká } \\
\text { p.n. }\end{array}$ & \\
\hline $\begin{array}{l}\text { Juniperus spp. } \\
\text { (Cupressaceae) } \\
0405244 / 1\end{array}$ & $\begin{array}{l}\text { juniper (dried } \\
\text { branches) }\end{array}$ & Ritual & $\begin{array}{l}\text { (I-II) }{ }^{\mathrm{LP}} \text { Xuwo p.n. } \\
\text { (III) }{ }^{\mathrm{EP}} \int \mathrm{utu} \text {. } u \text { p.n., } \\
{ }^{\mathrm{EP}} \int \mathrm{t} \varphi \mathrm{te} \text { p.n. }\end{array}$ & $\begin{array}{l}\text { xùuwó } \\
\text { p.n. }\end{array}$ & shug pa p.n. \\
\hline
\end{tabular}




\begin{tabular}{|c|c|c|c|c|c|}
\hline $\begin{array}{l}\text { Latin name, family, } \\
\text { specimen no. }\end{array}$ & English name & $\begin{array}{l}\text { Plant use } \\
\text { category }\end{array}$ & Xumi & Kami & TE \\
\hline $\begin{array}{l}\text { Pinus yunnanensis } \\
\text { Franch. } \\
\text { (Pinaceae) } \\
0406025 / 1\end{array}$ & pine & Ritual & $\begin{array}{l}\text { (I) }{ }^{\mathrm{LP}} \mathbf{t}^{\mathrm{h}} \tilde{\mathbf{J}}-\mathrm{si} \text { p.n.-tree } \\
(\mathrm{II}-\mathrm{III}){ }^{\mathrm{LP}} \mathbf{t}^{\mathrm{h}} \tilde{\mathbf{a}}-\mathrm{z} \tilde{\varepsilon} \text { p.n.- } \\
\text { tree }\end{array}$ & $\begin{array}{l}\mathbf{t}^{\mathrm{h}} \tilde{\tilde{\mathbf{J}}}-\mathrm{bí} \\
\text { pine- } \\
\text { needle }^{13}\end{array}$ & $\begin{array}{l}\text { thang bal } \\
\text { pine-needle }\end{array}$ \\
\hline $\begin{array}{l}\text { Rhododendron } \\
\text { trichostomum Franch. } \\
\text { (Ericaceae) } \\
040502 \text { 1/3; } 040608 \text { 7/1 }\end{array}$ & $\begin{array}{l}\text { rhododendron } \\
\text { species }\end{array}$ & Ritual & $\begin{array}{l}\text { (I) }{ }^{\mathrm{LP}} \text { sikje p.n. } \\
\text { (II) }{ }^{\mathrm{EP}} \mathrm{S}^{\mathrm{J}} \mathrm{k}^{\mathrm{h}} \mathrm{W} 3 \text { p.n. } \\
\text { (III) }{ }^{\mathrm{LP}} 6 \tilde{\mathrm{a}} \mathrm{k}^{\mathrm{h}} \mathrm{We} \text { p.n. }\end{array}$ & sìké p.n. & \\
\hline
\end{tabular}




\section{Plant Names Shared between Xumi and Kami}

Several observations can be made about the plant names shared between Xumi and Kami (Table 4). First, in half of all cases ("common bracken, eagle fern" [Prinsepia utilis Royle], "juniper” [Juniperus spp.], and "rhododendron” [Rhododendron trichostomum Franch.], in their majority ritual plant names), plant names are only shared in Upper Xumi and Kami, whereas corresponding forms in Middle and Lower Xumi are different. This reflects the fact that Upper Xumi is in an intensive contact situation with Kami, which favors borrowing. Notably, these shared forms do not have Tibetan etymologies and are therefore likely to be Xumi loanwords in Kami. That borrowing is clearly bidirectional between Xumi and Kami can be demonstrated with Kami plant names for some other plants in our collection, for instance, Excoecaria acerifolia Didr.

(medicinal): Kami /bjèkz̃́/; and “Cape myrtle” (Myrsine africana L.) (others): Kami /bùlí

bjèkz̃́/. Xumi names for these plants are distinct from the corresponding Kami names:

e.g., Upper Xumi /EP ${ }^{\mathrm{E}}$ ku-bje/ p.n.-leaf, and /LP gile-bjek̃̃/ p.n.-broom, respectively.

However, the use of the Xumi word for "broom" (Upper Xumi /RPbjekz̃/) in Kami forms

reveals Xumi as the source for these two plant names in Kami. (In Kami, these ritual plants are named after their use, which is ritual sweeping.)

Second, the two Kami forms that are identifiable with Tibetan roots ("pomegranate" [Punica granatum L.] and "juniper"), thus suggesting Tibetan as the source for the corresponding Xumi forms, are shared in all or almost all subvarieties of Xumi. This possibly suggests previous contacts between Xumi and Tibetans, distinct from the 
present-day Upper Xumi-Kami contact situation in the upper reaches of the Shuiluo River. (In the case of "pine" [Pinus yunnanensis Franch.], WT thang, the source of that plant name is more difficult to identify, given that the form in question is a widespread Tibeto-Burman etymon, *tan [Matisoff 2003:662].)

Finally, in the remaining two cases ("sweet flag, calamus" [Acorus calamus L.] and Cornus oblonga Wall.), the Tibetan etymology of the forms is uncertain, whereas standard Tibetan meaning equivalents of these plant names are distinct from the corresponding Kami forms. For example, the standard Tibetan meaning equivalent of "sweet flag, calamus" is shu dag nag po. This leaves Xumi (or alternatively, some external source) as the donor for the shared names. 
Table 5: Plant names shared between Xumi and Shuiluo Pumi

\begin{tabular}{|c|c|c|c|c|c|}
\hline $\begin{array}{l}\text { Latin name, } \\
\text { family, specimen } \\
\text { no. }\end{array}$ & $\begin{array}{l}\text { English } \\
\text { name }\end{array}$ & $\begin{array}{l}\text { Plant } \\
\text { use } \\
\text { category }\end{array}$ & Xumi & $\begin{array}{l}\text { Shuiluo } \\
\text { Pumi }\end{array}$ & $\begin{array}{l}\text { Wadu } \\
\text { Pumi }\end{array}$ \\
\hline $\begin{array}{l}\text { Juglans regia L. } \\
\text { (Juglandaceae) } \\
0404291 / 2\end{array}$ & walnut & $\begin{array}{l}\text { Fruit } \\
\text { Ritual }\end{array}$ & (I-III) ${ }^{\mathrm{RP}} \mathrm{q}^{\mathrm{h}}$ EIE p.n. & k'àrà p.n. & wùdú p.n. \\
\hline $\begin{array}{l}\text { Pteridium } \\
\text { aquilinum (L.) } \\
\text { Kuhn } \\
\text { (Dennstaedtiacea } \\
\text { e) } \\
0405131 / 3\end{array}$ & $\begin{array}{l}\text { common } \\
\text { bracken, } \\
\text { eagle fern }\end{array}$ & $\begin{array}{l}\text { Wild } \\
\text { food } \\
\text { Other }\end{array}$ & $\begin{array}{l}\text { (I) }{ }^{\mathrm{LP}} \text { deлe p.n., } \\
{ }^{\mathrm{RP}} \text { ejgə p.n. } \\
\text { (II) }{ }^{\mathrm{EP}} \text { dje.s p.n., }{ }^{\mathrm{R}} \mathrm{dj \varepsilon} \\
\text { p.n. } \\
\text { (III) }{ }^{\mathrm{H}} \mathrm{dj \varepsilon} \text { p.n. }\end{array}$ & dẫ̂ p.n. & dỗ p.n. \\
\hline
\end{tabular}




\begin{tabular}{|c|c|c|c|c|c|}
\hline $\begin{array}{l}\text { Latin name, } \\
\text { family, specimen } \\
\text { no. }\end{array}$ & $\begin{array}{l}\text { English } \\
\text { name }\end{array}$ & $\begin{array}{l}\text { Plant } \\
\text { use } \\
\text { category }\end{array}$ & Xumi & $\begin{array}{l}\text { Shuiluo } \\
\text { Pumi }\end{array}$ & $\begin{array}{l}\text { Wadu } \\
\text { Pumi }\end{array}$ \\
\hline $\begin{array}{l}\text { Salix cheilophila } \\
\text { C.K. Schneid. } \\
\text { (Salicaceae) } \\
040605 \text { 1/6; } \\
040608 \text { 5/1; } \\
040614 \text { 2/1 }\end{array}$ & sand willow & Other & $\begin{array}{l}\text { (I) }{ }^{\mathrm{RP}} \text { Jwe-hũ } \\
\text { willow-white } \\
\text { (II) }{ }^{\mathrm{EP}} \text { Jwa-pẽ } \\
\text { willow-white } \\
\text { (III) }{ }^{\mathrm{RP}} \text { Jwa- } \Phi \tilde{o} \\
\text { willow-white }{ }^{14}\end{array}$ & $\begin{array}{l}\text { rú-prh ồ rú- } \\
\text { prh̀̃̀ willow- } \\
\text { white }\end{array}$ & $\begin{array}{l}\text { ¡á-bồ } \\
\text { willow- } \\
\text { tree }\end{array}$ \\
\hline $\begin{array}{l}\text { Taraxacum } \\
\text { officinale agg. } \\
\text { (L.) Weber ex } \\
\text { F.H.Wigg. } \\
\text { (Asteraceae) } \\
0406141 / 5 ; \\
0410101 / 2\end{array}$ & dandelion & Other & $\begin{array}{l}\text { (I) }{ }^{\mathrm{RP}} \text { tşutse p.n. } \\
\text { (II-III) }{ }^{\mathrm{RP}} \mathrm{t} \int u t \int e \text { p.n. }\end{array}$ & $\begin{array}{l}\text { tsùtsútsátsà } \\
\text { p.n. }\end{array}$ & $\begin{array}{l}\text { qípù- } \\
\text { pètsə̀ } \\
\text { cuckoo- } \\
\text { flower }^{15}\end{array}$ \\
\hline
\end{tabular}




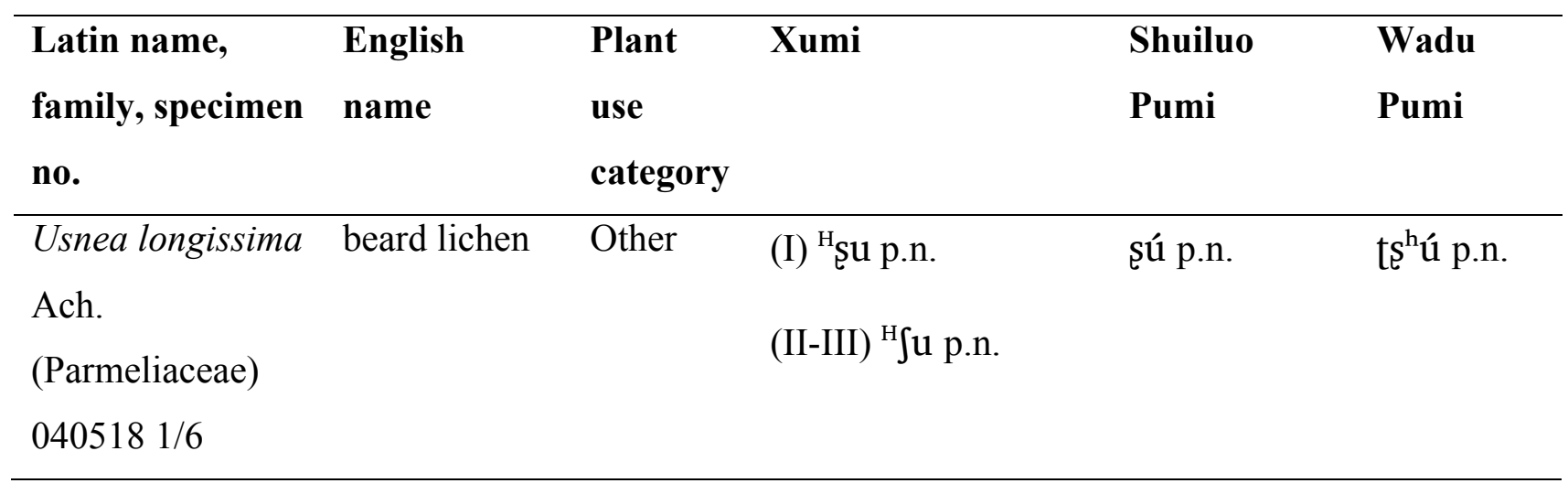




\section{Plant Names Shared between Xumi and Pumi}

Of the five plant names that are shared by Xumi and Pumi (Table 5), three names are also shared in Shuiluo Pumi and Wadu Pumi: "common bracken, eagle fern," "sand willow" (Salix cheilophila C.K. Schneid.), and "beard lichen" (Usnea longissima Ach.). The status of these forms, as either cognates in Pumi and Xumi or Pumi loan words in Xumi, is difficult to establish with certainty. In one case ("beard lichen"), the shared form is a Pumi loanword in Xumi, as confirmed by our language consultants. This type of lichen grows at high altitudes, further from the subtropical shrub vegetation belt, which is home to the Xumi group. The Xumi traditionally use this type of lichen as a sponge, and refer to this species by its Pumi name. Conversely, the names for "common bracken, eagle fern" and "sand willow", which are both local common wild species, may be any of the following possibilities: (a) cognates in Xumi and Pumi, (b) Pumi loanwords in Xumi, (c) Xumi loanwords in Pumi, or (d) any combination of (a) through (c).

In two cases ("walnut" [Juglans regia L.] and "dandelion" [Taraxacum officinale agg. (L.) Weber ex F.H.Wigg.]), Wadu Pumi forms are distinct from Shuiluo Pumi forms. Of these, the word for "walnut" deserves a special note due to its cultural importance in the Himalayan region. This crop, traditionally cultivated by different local ethnic groups has until recently been the main source for oil (Weckerle et al. 2005a:287). Given its importance, the name for this plant has been documented in previous studies of local languages (and in different varieties of Pumi and Tibetan). The list of names for "walnut" in the Tibeto-Burman languages of China in Huang et al. (1992:134) reflects three major sources for this plant name (Table 6). The distribution of the latter form is similar to that 
of $/ \mathrm{k}^{\mathrm{h}} \mathrm{asə} /$ (or variants) "maize" and associated with Muli and surrounding areas. 
Table 6: Sources for 'walnut' in the local languages

\begin{tabular}{|c|c|}
\hline Source & Examples \\
\hline Tibetan star ka or star ga & Lanping Pumi, $/ \mathrm{ta}^{55} \mathrm{qa}^{55} /$ (Huang et al. 1992:134) \\
\hline Naxi $/ g v^{33} \mathrm{dp}^{31} /$ & $\begin{array}{l}\left.\text { Shuiluo Kami /kùdú/, Wadu Pumi, /wùdú/, cf. [во }{ }^{33} \mathrm{du}^{33}\right] \text { in } \\
\text { Jiubao Naxi }\end{array}$ \\
\hline $\begin{array}{l}\text { Unknown origin, } / \mathrm{k}^{\mathrm{h}} \mathrm{ara} / \text { (with } \\
\text { various surface tones) }\end{array}$ & $\begin{array}{l}\text { Xumi, Shuiluo, Yiji, and Jiulong varieties of Pumi, and some } \\
\text { other Tibeto-Burman languages of Muli, e.g. Lizu, } / \mathrm{k}^{\mathrm{h}} \mathrm{e}^{55} \mathrm{\lrcorner} \partial^{31} / \text {, or } \\
\text { Namuzi, } / \mathrm{q}^{\mathrm{h}} \mathrm{a}^{33} 1 \mathrm{a}^{55} / \text { (Lizu and Namuzi forms are from firsthand } \\
\text { fieldwork) }\end{array}$ \\
\hline
\end{tabular}


Table 7: Shared plant names in Kami and Shuiluo Pumi

\begin{tabular}{|c|c|c|c|c|c|}
\hline $\begin{array}{l}\text { Latin name, family, } \\
\text { specimen no. }\end{array}$ & $\begin{array}{l}\text { English } \\
\text { name }\end{array}$ & $\begin{array}{l}\text { Plant use } \\
\text { category }\end{array}$ & Kami & TE & $\begin{array}{l}\text { Shuiluo } \\
\text { Pumi }\end{array}$ \\
\hline $\begin{array}{l}\text { Cyrtomium falcatum (L. } \\
\text { f.) C. Presl } \\
\text { (Dryopteridaceae) } \\
0405302 / 3\end{array}$ & & Medicinal & lè-lé p.n. & & ljæ̀-ljæ̀ p.n \\
\hline $\begin{array}{l}\text { Paeonia lactiflora Pall. } \\
\text { (Paeoniaceae) } \\
040421 \text { 2/5; } 040615 \text { 1/1 }\end{array}$ & peony & Medicinal & tấphì̀ p.n. & & dǐ̃phì p.n. \\
\hline $\begin{array}{l}\text { Cupressus funebris Endl. } \\
\text { (Cupressaceae) } \\
040430 \text { 1/1; } 050401 \text { 4/1 }\end{array}$ & $\begin{array}{l}\text { Chinese } \\
\text { weeping } \\
\text { cypress }\end{array}$ & Ritual & tsấdế p.n. & $\begin{array}{l}\text { tsan dan } \\
\text { sandalwood }\end{array}$ & tsếdî̀ p.n. \\
\hline
\end{tabular}




\section{Plant Names Shared between Kami and Pumi}

Kami and Shuiluo Pumi only share three plant names (Table 7). The sources of the shared forms are relatively transparent. In the case of "peony" (Paeonia lactiflora Pall.), used in Chinese herbal medicine, the source of the form is Mandarin Chinese, danpi (丹皮), literally “root bark of tree peony." On the other hand, in the case of Chinese weeping cypress ( Cupressus funebris Endl.), which is traditionally used as rit incense by both groups, the source is clearly Tibetan, WT tsan dan "sandalwood."

The case of Cyrtomium falcatum (L. f.) C. Presl is more complicated. Tibetan i unlikely to be the source for the form, as the Kami name has no known Tibetan etymology. Wadu Pumi has no name for the plant, whereas the name for the plant in Y Pumi is [pĩ̀njæ̌]. The source of borrowing in this case therefore remains to be investigated.

All in all, Kami and Shuiluo Pumi have very few plant names in common. This reflects a distant genetic relationship between the two languages and suggests relativel little contact between the two groups, at least in Shuiluo Valley. 
Table 8: Plant names shared by Xumi, Kami, and Shuiluo Pumi

\begin{tabular}{llllll}
\hline $\begin{array}{l}\text { Latin name, family, } \\
\text { specimen no. }\end{array}$ & $\begin{array}{l}\text { English } \\
\text { name }\end{array}$ & $\begin{array}{l}\text { Plant } \\
\text { use } \\
\text { category }\end{array}$ & Xumi & Kami & Shuiluo \\
Pumi
\end{tabular}




\begin{tabular}{|c|c|c|c|c|c|c|}
\hline $\begin{array}{l}\text { Latin name, family, } \\
\text { specimen no. }\end{array}$ & $\begin{array}{l}\text { English } \\
\text { name }\end{array}$ & $\begin{array}{l}\text { Plant } \\
\text { use } \\
\text { category }\end{array}$ & Xumi & Kami & TE & $\begin{array}{l}\text { Shuiluo } \\
\text { Pumi }\end{array}$ \\
\hline $\begin{array}{l}\text { Mentha spicata L. } \\
\text { (Lamiaceae) } \\
0406271 / 4\end{array}$ & $\operatorname{mint}$ & $\begin{array}{l}\text { Wild } \\
\text { food } \\
\text { Medicina } \\
1\end{array}$ & $\begin{array}{l}\text { (I) }{ }^{\mathrm{LP} h i ̃-} \text {-̃zyy person- } \\
\text { p.n., }{ }^{\mathrm{LP}} \tilde{\mathrm{J} z i 1}{ }^{16} \text { p.n. } \\
\text { (II) }{ }^{\mathrm{RP}} \text { Jõ-õzĩ horse- } \\
\text { p.n., }{ }^{\mathrm{EP}} \tilde{\text { Õzĩ p.n. }} \\
\text { (III) }{ }^{\mathrm{EP}} \tilde{\mathrm{O}} 3 \mathrm{e} \text { p.n. }\end{array}$ & 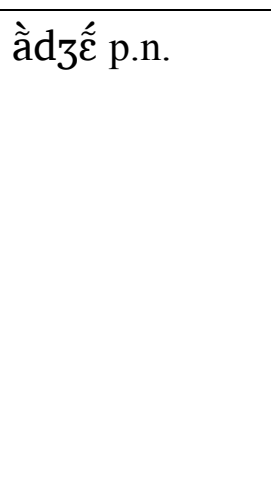 & & ì̀dzî́ p.n. \\
\hline $\begin{array}{l}\text { Aster lavandulifolius } \\
\text { Hand.-Mazz. } \\
\text { (Asteraceae) } \\
0405291 / 1\end{array}$ & & Ritual & $\begin{array}{l}\text { (I) }{ }^{\mathrm{EP}} \text { etş̃̃k3.̣bu p.n. } \\
\text { (II) }{ }^{\mathrm{EP}} \text { etsõkex̦bu p.n. } \\
\text { (III) }{ }^{\mathrm{RP}} \text { etşãkepu p.n. }\end{array}$ & àtsốkàpù p.n. & & $\begin{array}{l}\text { ètốkèpù } \\
\text { p.n. }\end{array}$ \\
\hline $\begin{array}{l}\text { Lithospermum } \\
\text { erythrorhizon } \\
\text { Siebold \& Zucc. } \\
\text { (Boraginaceae) } \\
210210 \_1\end{array}$ & $\begin{array}{l}\text { gromwell } \\
\text { root }\end{array}$ & Ritual & 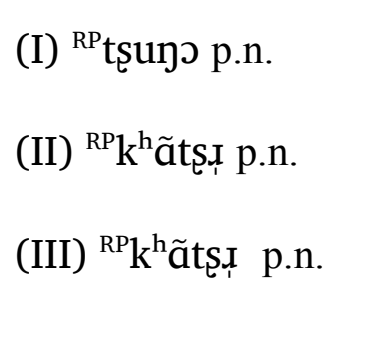 & Ndż̀̀ý p.n. & 'bri mog p.n. & xồtş́ p.n. \\
\hline
\end{tabular}




\begin{tabular}{|c|c|c|c|c|c|}
\hline $\begin{array}{l}\text { Latin name, family, } \\
\text { specimen no. }\end{array}$ & $\begin{array}{l}\text { English } \\
\text { name }\end{array}$ & $\begin{array}{l}\text { Plant } \\
\text { use } \\
\text { category }\end{array}$ & Xumi & Kami & $\begin{array}{l}\text { Shuiluo } \\
\text { Pumi }\end{array}$ \\
\hline $\begin{array}{l}\text { Osyris quadripartita } \\
\text { Salzm. ex Decne. } \\
\text { (Santalaceae) } \\
0405291 / 2 ; 040502 \\
1 / 1 ; 0504021 / 1\end{array}$ & $\begin{array}{l}\text { wild tea } \\
\text { plant }\end{array}$ & Ritual & $\begin{array}{l}\text { (I) }{ }^{\mathrm{RP}} \text { ekex p.n. } \\
\text { (II) }{ }^{\mathrm{EP}} \text { ekexu p.n. } \\
\text { (III) }{ }^{\mathrm{RP}} \text { ekexu p.n. }\end{array}$ & àkárù p.n. & èkárà p.n. \\
\hline $\begin{array}{l}\text { Acer spp. } \\
\text { (Aceraceae) } \\
0406075 / 1\end{array}$ & maple & Other & 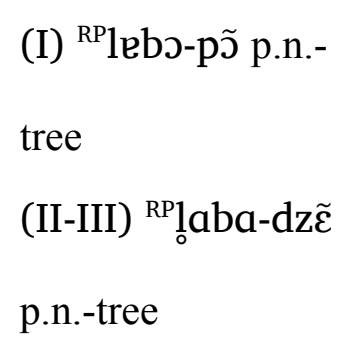 & làbó p.n. & $\begin{array}{l}\text { lépwát }{ }^{\mathrm{h}} \mathrm{á}- \\
\text { bõ̀ p.n.-tree }\end{array}$ \\
\hline $\begin{array}{l}\text { Catalpa bungei } \\
\text { C.A.Mey. } \\
\text { (Bignoniaceae) } \\
040614 \text { 1/1 }\end{array}$ & $\begin{array}{l}\text { Manchurian } \\
\text { catalpa }\end{array}$ & Other & $\begin{array}{l}\text { (I) }{ }^{\mathrm{EP}} \mathrm{ts}^{\mathrm{h}} \tilde{\partial} \text {-buxu ?- } \\
\text { flower } \\
\text { (III) }{ }^{\mathrm{RP}} \mathrm{k}^{\mathrm{h}} \tilde{\mathrm{e}}-\mathrm{w} \varepsilon \\
\text { mulberry-leaf }\end{array}$ & 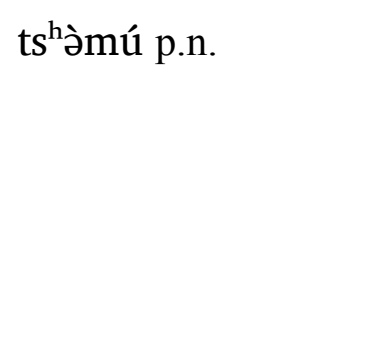 & ts ámó p.n. \\
\hline
\end{tabular}




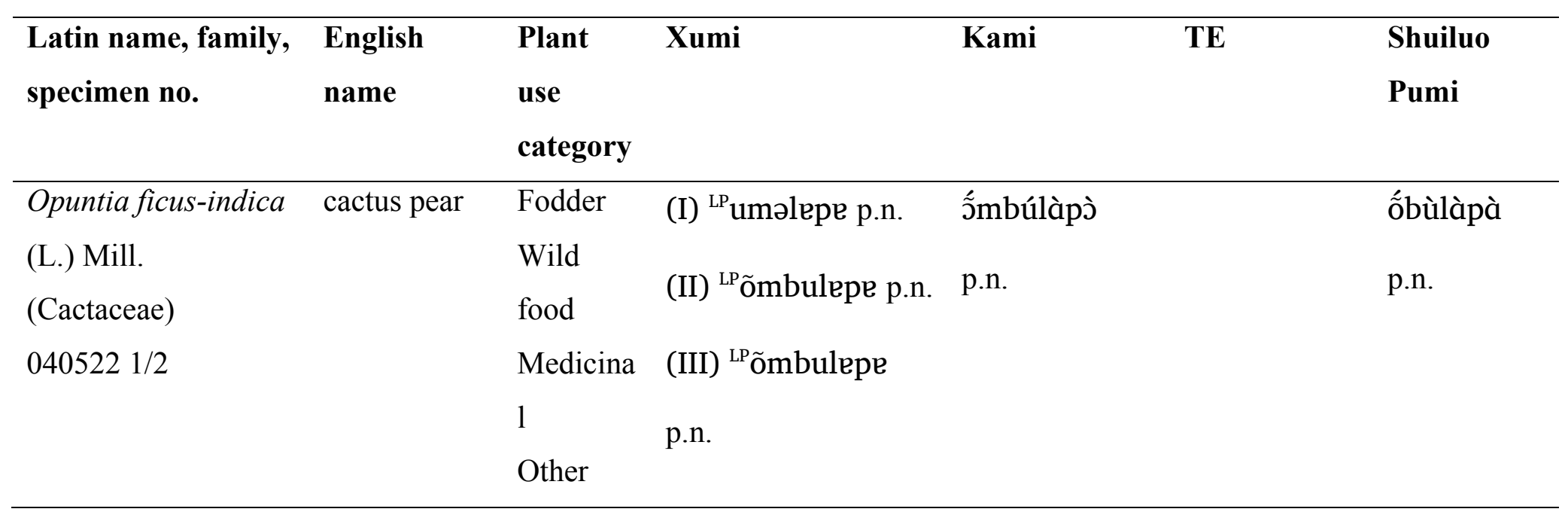




\section{Plant Names Shared in Xumi, Kami, and Shuiluo Pumi}

The high proportion of shared plant names in Xumi, Kami, and Shuiluo Pumi (Table 8) is remarkable. This is because these three languages are not closely related, as can be observed on the basis of field crop names. Furthermore, these languages do not appear to have been in the past in situations of close contact that would simultaneously involve all three languages (as can be observed on the basis of plant names shared between Kami and Pumi).

The source of borrowing for the shared forms can be identified with some certainty in two cases, "pear" (Pyrus sp.) and "gromwell root" (Lithospermum erythrorhizon Siebold \& Zucc.). Pear was introduced in the area in the 1970s (Muli Gazetteers 1995:267). Not surprisingly, the name for the plant in the three languages is a loanword from Mandarin Chinese: xueli (雪梨). It may not be accidental that the Chinese borrowing for this plant name is attested in the Xumi variety of Pingweng, in the middle reaches of the Shuiluo River. Pingweng is the administrative seat of Shuiluo Township, where Chinese is the language of administration. Conversely, the name for "pear" in the Upper and Lower varieties of Xumi is a native Xumi term.

Gromwell root is a ritual plant that is used for dying dough figures, which are an important component of local Tibetan Buddhist rituals, shared by all local groups. The Tibetan etymon 'bri is likely the source for the form in the three languages. Upper Xumi (/RP tsuy /) and Kami (/Ndz̨ə̀yว́/) both appear to reflect WT 'bri mog. In Middle and

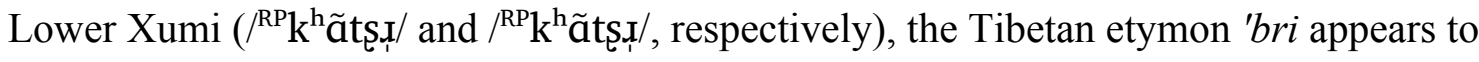


be preceded by the root $/ \mathrm{k}^{\mathrm{h}} \mathrm{a} /$ of unknown etymology. Shuiluo Mosuo and Naxi names for "gromwell root" are similar to that in Middle and Lower Xumi $\left(\left[\mathrm{k}^{\mathrm{h}} \mathrm{a}^{33} \mathrm{ndz} \partial^{33}\right]\right.$ and $\left[\mathrm{k}^{\mathrm{h}} \mathrm{a}^{33} \mathrm{ndz} \bigodot^{35}\right]$, respectively). (Wadu Pumi has a different name for this plant, /èdzí/. We do not know the names for this plant in the Naxi and Mosuo varieties spoken in the area around Wadu.)

For the remaining seven plant names that are shared by Xumi, Kami, and Pumi, the Kami forms could not be identified with known Tibetan roots, and their Written Tibetan meaning equivalents are distinct from the local Kami names. Examples include “mint”, Kami /ầd3ẑ́,/, WT meaning equivalent dngul par khang; Aster lavandulifolius Hand.-Mazz., Kami /àtsốkàpù/, WT meaning equivalent lug mig; and "maple" (Acer spp.), Kami /làbó/, WT meaning equivalent $g \cdot y a^{\prime}$ shing. Interestingly, most of the plant names that are shared by Xumi, Kami, and Shuiluo Pumi, are also shared by some other northern Pumi varieties (Wadu Pumi and Jiulong Pumi), as well as by the Shuiluo varieties of Mosuo and Naxi (see Table 9; Jiulong Pumi data are from Huang et al. [1992:132]). 
Table 9: Plant names shared by Shuiluo languages with northern Pumi varieties and Lianmu Mosuo

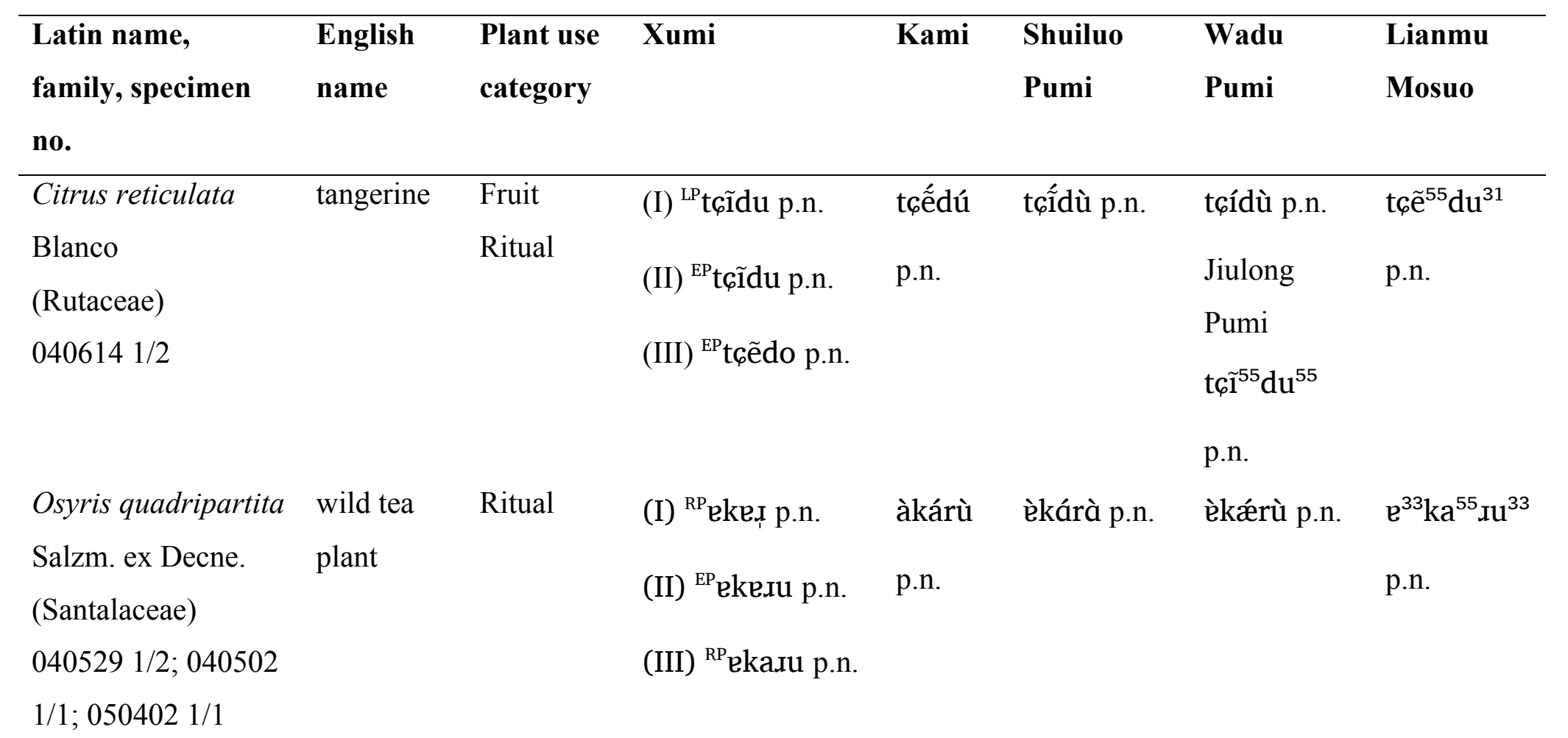




\begin{tabular}{|c|c|c|c|c|c|c|c|}
\hline $\begin{array}{l}\text { Latin name, } \\
\text { family, specimen } \\
\text { no. }\end{array}$ & $\begin{array}{l}\text { English } \\
\text { name }\end{array}$ & $\begin{array}{l}\text { Plant use } \\
\text { category }\end{array}$ & Xumi & Kami & $\begin{array}{l}\text { Shuiluo } \\
\text { Pumi }\end{array}$ & $\begin{array}{l}\text { Wadu } \\
\text { Pumi }\end{array}$ & $\begin{array}{l}\text { Lianmu } \\
\text { Mosuo }\end{array}$ \\
\hline $\begin{array}{l}\text { Opuntia ficus-indica } \\
\text { (L.) Mill. } \\
\text { (Cactaceae) } \\
0405221 / 2\end{array}$ & $\begin{array}{l}\text { cactus } \\
\text { pear }\end{array}$ & $\begin{array}{l}\text { Fodder } \\
\text { Wild food } \\
\text { Medicinal } \\
\text { Other }\end{array}$ & $\begin{array}{l}\text { (I) }{ }^{\mathrm{LP}} \text { uməlepe } \\
\text { p.n. } \\
\text { (II-III) } \\
\text { LPõmbulepe p.n. }\end{array}$ & $\begin{array}{l}\text { J̃́mbú } \\
\text { làpò } \\
\text { p.n. }\end{array}$ & $\begin{array}{l}\text { ốbùlàpà } \\
\text { p.n. }\end{array}$ & $\begin{array}{l}\text { ốbúlàpà } \\
\text { p.n. }\end{array}$ & $\begin{array}{l}\tilde{\mathrm{o}}^{55} \mathrm{mbu}^{33} \\
\mathrm{le}^{33} \mathrm{po}^{33} \\
\text { p.n. }\end{array}$ \\
\hline
\end{tabular}



Most plant names that are shared in Xumi, Kami, and Shuiluo Pumi are wild species, of which the majority are of little or no known cultural significance (such as "Manchurian catalpa" [Catalpa bungei C.A.Mey.] or "cactus pear" [Opuntia ficus-indica (L.) Mill.]). The distribution of these plant names corresponds again to Muli and surrounding areas (i.e., Jiulong, as exemplified by Jiulong Pumi; Muli, as exemplified by Shuiluo and Yiji Pumi; Ninglang, as exemplified by Wadu Pumi). Given that names for local plant species are typically borrowed by migrants newly moved into the area (e.g., Haspelmath 2008:51), shared plant names discussed in this section may have been borrowed by the present-day inhabitants of Shuiluo from an indigenous language.

\section{Discussion and Conclusion}

In this study we used shared plant names (both cognates and loanwords) in five Tibeto-Burman languages, with the purpose of gaining insight into the complex relationships between these languages and their contact history. Here is a summary of our major findings.

Our study of names for field crops corroborates existing historical and linguistic accounts of Kami, Xumi, Pumi, Naxi, and Mosuo. Kami is most distantly related to all other languages spoken in Shuiluo, as it has a distinct set of field crop names, dissimilar to those in all other local languages. Xumi is likely closely related to $\mathrm{Na}$ languages, as they share most names for field crops of native origin and of early introduction. Pumi is 
less closely related to either Xumi or Na languages, as it only shares two forms with these languages.

Likely candidates for loanwords in the local languages (such as "maize," "pear," "gromwell root") point to multiple overlaying cultural influences: (a) Tibetan, represented by ritual plant names (shug pa "juniper," 'bri mog "gromwell root," tsan dan "Chinese weeping cypress"); (b) (recent and marginal) Chinese (xueli "pear" and danpi "peony"); (c) local influential cultures and languages: (i) $\mathrm{Na}$, associated with the area to

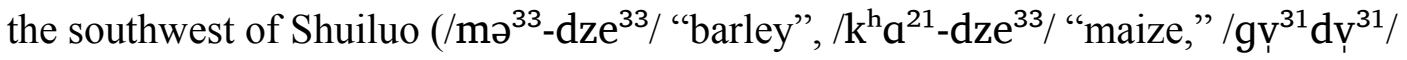
"walnut"); and (ii) a linguistic variety, which appears native to Muli and surrounding areas (corresponding to the area of the distribution of northern Pumi varieties and some other Tibeto-Burman languages, such as Xumi or Lizu). The latter source accounts for the majority of shared plant names, including some plants of high cultural significance (such as $/ \mathrm{k}^{\mathrm{h}} \mathrm{aş} /$ [or variants] "maize" or $/ \mathrm{k}^{\mathrm{h}} \mathrm{ara} /$ [or variants] "walnut") and names for many local wild and semi-wild varieties.

The scarcity of loan influence of Tibetan (with only four loan words across all categories of use: bse ma "pomegranate," shug pa "juniper," 'bri mog "gromwell root," tsan dan "Chinese weeping cypress") is surprising, given that the area traditionally falls in the sphere of Tibetan influence. The low degree of loan influence is likely due to the location of the study site at the very periphery of the Tibetan world. This is also suggested by the fact that only a few Kami plant names have Tibetan etymology. As 
newcomers to the area, Tibetans likely borrowed many terms for local flora from the indigenous language(s).

Overall, there is only a weak correlation between the distributional patterns of shared plant names in the local languages and the eight categories of use represented in our plant collection. This suggests that the area is likely to have long been inhabited by egalitarian communities, in which multilingualism is the normal mode of linguistic interaction and no clear dominant language can be discerned.

Plant names shared between most local languages (Tables 8 and 9) combine in equal proportions, ritual plant names and names for plants of little or no known cultural significance ("others"). The former reflects the fact that the local groups share ritual practices. The latter suggests that the majority of the local ethnic groups are newcomers into the area borrowing names for local plants from some indigenous language(s). We note that Xumi and Pumi are two languages that share most plant names in the category "others" (seven shared plant names in total, see Tables 5 and 8). This is in stark contrast to the very few plant names that they share in all other categories of use combined. This suggests that either Xumi or Pumi may be the original donor or the language that was most in contact with the donor after its arrival into the area.

The findings above have implications that go beyond the primary focus of our study of shared plant names in Shuiluo languages.

First, further linguistic work in the area needs to take into account the complexity of past contacts between the local ethnic groups, as can be glimpsed through their plant vocabularies. Related processes include (a) bidirectional borrowings between groups (as 
in the case of Upper Xumi and Kami), (b) multi-layered contacts with different varieties of the same language (as in the case of Xumi borrowings from Tibetan), and (c) possibly, parallel borrowings from some yet unidentified local language(s) (as in the case of plant names in the category "others").

Second, these complex contact scenarios have implications for our understanding of the regional sociolinguistic history. In addition to Tibetan and Chinese, which are traditionally seen as the most important sources of cultural influences in the area (e.g., Huang 1991:367), it is important to recognize local sources of loanwords: on the one hand, Na languages and, on the other hand, some other languages spoken in Muli and neighboring areas, whose identity still needs to be revealed. Careful identification of these indigenous languages is of significance for our understanding of the local linguistic history, and it also may shed light on the development and spread of some characteristic areal features (such as directional prefixes or multiple existential verbs; e.g., Sun 2001).

Third, using plant names to investigate the relationship and the history of contact between languages in complex multilingual areas, such as the one discussed in this paper, may be a promising way to provide independent insights into the local linguistic history. Finally, linguistic research in such areas needs to go hand in hand with interdisciplinary teamwork and analysis of the local languages in the specific cultural and historical contexts that surround and shape them.

\section{Notes}


${ }^{1}$ Place and ethnic names use the most commonly utilized and institutionalized names in the national Mandarin Chinese language (therefore using pinyin transcription and Chinese characters). Locations that have Tibetan names provide those in Wylie's (1959) standard transliteration system of Written Tibetan.

${ }^{2}$ Detailed phonological analyses of Xumi, Kami, and Pumi can be found in Chirkova and Chen (2013) and Chirkova et al. (2013) for Xumi; Chirkova (2014) for Kami; Jacques (2011) for Shuiluo Pumi; and Daudey (2014) for Wadu Pumi. We generally follow the original tone notation as adopted in these phonological sketches. Tone notation in Xumi is provided in superscript letters: " $\mathrm{R}$ " stands for a rising tone; " $\mathrm{H}$ " stands for a high tone; "EP" (equally-prominent) stands for a tonal pattern in which there is no salient rise or fall over any of the syllables, which both carry high-level pitch contours; "LP" (leftprominent) stands a prominence pattern, in which the high f0 peak is realized before the end of the first syllable, where the pitch starts to fall already and it continues to fall in the second syllable; and "RP" (right-prominent) stands for a tonal pattern in which the high f0 peak is realized over the last syllable of the word. Tone notation in Kami and Pumi is provided in tone diacritics: "á" stands for a high tone, "à" stands for a low tone, "ă" stands for a rising tone and "â" stands for a falling tone. Shuiluo Pumi transcriptions in the text are by Daudey and Gerong Pincuo. Their analysis of Shuiluo Pumi differs slightly from that in Jacques (2011). Differences between the two analyses relate to vowel quality interpretation, no clear evidence in Daudey and Gerong Pincuo's analysis 
for the presence of a voiceless velar nasal, of a separate glottal fricative set and of $/ \mathrm{s}^{\mathrm{h}} /$, and the presence in their analysis of the initial clusters $/ \mathrm{pr} /, / \mathrm{p}^{\mathrm{h}} \mathrm{r} /, / \mathrm{br} /$.

${ }^{3}$ Tibetans live in the Tibetan Autonomous Region (WT bod rang skyong ljongs), in the western part of Sichuan Province (including the autonomous counties of Ganzi [甘孜], WT dkar mdzes, and Aba[阿坝], WT rnga ba), in the northern part of Yunnan (云南) Province (Diqing, [迪庆], WT bde chen, Autonomous Prefecture), and in Qinghai (青海, WT mtsho sngon) and Gansu (甘肃) Provinces.

${ }^{4}$ In addition to Muli, Pumi also live in the counties of Yanyuan (盐源) and Jiulong (九龙, WT brgyad zur) in Sichuan Province, and in the counties of Lanping (兰坪), Ninglang ( 宁蒗), Yongsheng (永胜), Lijiang (丽江), Yunxian (云县), and Weixi (维西), all in Yunnan Province.

${ }^{5}$ Naxi and Mosuo live in Muli and the counties of Yanyuan, Jiulong, Lanping, Ninglang, Yongsheng, Lijiang, Yunxian, and Weixi (see Note 4), and in Zhongdian (中甸, WT rgyal thang), Huaping (华坪), Deqin (德钦, WT bde chen), Mangkang (芒康, WT smar khams), Batang (巴塘, WT 'ba' thang), and Yanbian (盐边) Counties in Sichuan and Yunnan Provinces (Guo and He 1994:1-4; Lu 2001:1).

${ }^{6}$ We use the term "(speech) varieties" to refer to different local varieties of the studied languages, and the term "dialect" to indicate the officially recognized dialects of the Tibetan, Pumi, and Na languages. Hence, Kami is a local variety of the Kham Tibetan dialect; Shuiluo and Wadu Pumi are varieties of the Northern dialect of Pumi. 
${ }^{7}$ For each plant name we provide a scientific Latin name together with the specimen number, (whenever available) a common English name, categories of plant use, meaning equivalents in the local languages, and Tibetan etymologies underlying Kami forms (in italics). Literal translations are provided for all morphemes, whose meaning could be identified. In literal translations, "p.n." stands for "proper name” and indicates nonanalyzable native terms. Uncertain origins are indicated by question marks in the corresponding syllable slot. In the column "Xumi," "(I)" stands for the data collected in the village of Lanman, “(II)" stands for the data collected in the village of Pingweng, and "(III)" stands for the data collected in the village of Mianbang.

${ }^{8}$ Naxi forms are from Huang et al. (1992:135-139, 144), Mosuo forms are from firsthand fieldwork. $\mathrm{TE}=$ Tibetan etymology; $\mathrm{LB}=$ Lolo-Burmese etymon.

${ }^{9}$ Middle Xumi and Shuiluo Pumi distinguish between two kinds of "highland barley": (1) “white highland barley,” Xumi / ${ }^{\mathrm{H}}$ zõ/, Pumi /kồtsố p phỗ̂/; and (2) “black highland barley,” Xumi / ${ }^{\mathrm{EP}}$ zõ-ne/, Pumi /kồtsố njæ̀ká/.

${ }^{10}$ The second syllable of this form is a lenited form of $/{ }^{\mathrm{H}} \mathrm{q}^{\mathrm{h}} \mathrm{\partial} /$ "bitter".

${ }^{11}$ This type of millet is grown on less fertile land. It is planted together with rice and used predominantly for fodder.

${ }^{12}$ Note that the Ludian form can be tentatively analyzed as consisting of the roots "wheat" (/se $\mathrm{e}^{55} /$, Lu 2001:378) and "long" (/s $\tilde{\mathrm{A}}^{55} /$, Lu 2001:442). The same is possibly also true for the Qinghua form (the roots for "wheat" and "long" in that dialect are $/ \mathrm{Se}^{55} /$ 
and $/ \mathrm{s}^{5}{ }^{5} /$, respectively, $\left.\mathrm{Lu} 2001: 378,442\right)$. The first syllable of the Xinyingpan form

may also be related to "wheat" $\left(/ \mathrm{s} \partial^{55} /\right)$. The etymology of the second syllable is unclear.

${ }^{13}$ The name refers to the specimen, which was a tip of a pine branch.

${ }^{14}$ The second morpheme in the Upper and Lower Xumi forms is likely to be a lenited form of the root for "white": Upper Xumi $/{ }^{R P} p^{\mathrm{h}} \mathrm{u}$-tçe-tce/, Lower Xumi $/{ }^{\mathrm{RP}} \mathrm{p}^{\mathrm{h}} \mathrm{t}$-tce-tce/.

${ }^{15}$ The name for "dandelion" in Wadu Pumi, /qípù-pètsə̀/, lit. "cuckoo-flower," refers to the overlap of time in spring when the cuckoo appears and the dandelion starts to bloom.

${ }^{16}$ The second syllable of this form is likely to be a lenited form of $/ \mathrm{d} 3 /$.

\section{Acknowledgments}

We would like to thank our language consultants in Shuiluo, Wadu, and Yiji for their help in identifying plant names, Edwin Schmitt, Gerald Roche, and the three anonymous reviewers of this paper; and the journal's editors for their helpful comments and suggestions. We are also grateful to Yang Yongping (杨永平) and Han Xi (韩希) of the Kunming Institute of Botany and our interpreter Chen Yulin (陈玉林) for their help in organizing and carrying out the fieldwork, and to the Lijiang Teacher's College (丽江师 范高等专科学校) for their support of Daudey's and Gerong Pincuo's research on Pumi. 
We gratefully acknowledge the financial support of (1) Agence Nationale de la

Recherche of France (grant number ANR-07-JCJC-0063); (2) Endangered Languages

Documentation Programme (ELDP, grant number MDP0257); and (3) Yunnan Provincial

Education Bureau (云南省教育厅).

\section{References Cited}

Andersen, H. 2003. Introduction. In Language Contacts in Prehistory: Studies in Stratigraphy, edited by H. Andersen, pp. 1-10. John Benjamins, Amsterdam and Philadelphia.

Atran, S. 1998. Folk Biology and the Anthropology of Science: Cognitive Universals and Cultural Particulars. Behavioral and Brain Sciences 21:547-609.

Bellwood, P. 1984-1985. The Austronesian dispersal and the origin of languages. Asian Perspectives 26:107-117.

Berlin, B., D. E. Breedlove, and P. H. Raven. 1974. Principles of Tzeltal Plant Classification. Academic Press, New York and London.

Bradley, D. 1997a. Tibeto-Burman Languages and Classification. In Papers in Southeast Asian Linguistics No.14: Tibeto-Burman Languages of the Himalayas, edited by D. Bradley, pp. 1-71. Australian National University, Canberra.

Bradley, D. 1997b. What did they Eat? Grain Crops in the Burmic Groups. Mon-Khmer Studies 27:161-170.

Bradley, D. 2011. Proto-Tibeto-Burman grain crops. Rice 4:134-141.

Brown, C. H. 1999. Lexical Acculturation in Native American languages. Oxford University Press, New York and Oxford.

Chirkova, K. 2009. Shixing, a Tibeto-Burman Language of South-West China: A Grammatical Sketch with two Appended Texts. Linguistics of the Tibeto-Burman Area 32.1:1-90.

Chirkova, K. 2012. The Qiangic Subgroup from an Areal Perspective: A Case Study of Languages of Muli. Language and Linguistics 13.1:133-170.

Chirkova, K. 2014. A First Look at Kami, the Tibetan Dialect of Muli. In Phonological Profiles of Little-Studied Tibetic Varieties (Language and Linguistics Monograph Series 55), edited by J. T.-S. Sun, pp. 1-77. Academia Sinica, Taipei.

Chirkova, K., and Y. Chen. 2013. Lower Xumi (Illustrations of the IPA). Journal of the International Phonetic Association 43.3:363-379.

Chirkova, K., Y. Chen, and T. Kocjančič Antolik. 2013. Upper Xumi (Illustrations of the IPA). Journal of the International Phonetic Association 43.3:381-396.

Daudey, H. 2014. A Grammar of Wadu Pumi. Unpublished Doctoral Dissertation, Department of Linguistics, La Trobe University, Melbourne, Australia. 
Gammerman, A. F., and B. V. Semichov. 1963. Slovar' tibetsko-latino-russkix nazvanij lekarstvennogo rastitel'nogo syr'ja, primenjaemogo v tibetskoj meditsine [A Tibetan-Latin-Russian Dictionary of Tibetan Medicinal Plants]. Burjatskoe knizhnoe izdatel'stvo, Ulan-Ude.

Gesang Jumian 格桑居冕 (skal bzang 'gyur med). 1964. Zangyu Fangyan Gaiyao 《藏 语方言概要》/ Bod kyi yul skad gces bsdus / Essentials of Tibetan Dialects. Zhongyang Minzu Xueyuan Yuwenxì 中央民族学院语文系, Beijing.

Guo, D. 郭大烈 and Z. He 和志武. 1994. Naxizu Shi 《纳西族史》 [History of the Naxi]. Sichuan Minzu Chubanshe 四川民族出版社, Chengdu.

Haspelmath, M. 2008. Loanword Typology: Steps Towards a Systematic Cross-linguistic Study of Lexical Borrowability. In Aspects of Language Contact: New Theoretical, Methodological and Empirical Findings with Special Focus on Romancisation Processes, edited by T. Stolz, D. Bakker, and R. Salas Palomo, pp. 43-62. Mouton de Gruyter, Berlin and New York.

He, J. 和即仁 and Zh. Jiang 姜竹仪. 1985. Naxiyu Jianzhi 《纳西语简志》 [A brief description of the Naxi language]. Minzu Chubanshe 民族出版社, Beijing.

Ho, P. 1955. The Introduction of American Food Plants into China. American Anthropologist 57.2:191-201.

Ho, P. 1975. The Cradle of the East: An Inquiry into the Indigenous Origins of Techniques and Ideas of Neolithic and Early Historic China, 5000-1000 B.C. Chinese University of Hong Kong, University of Chicago Press, Hong Kong, Chicago.

Hsu, E. 1998. Introduction. In Naxi and Moso Ethnography: Kin Rites and Pictographs, edited by M. Oppitz and E. Hsu, pp. 9-19. Völkerkundemuseum der Universität Zürich, Zürich.

Huang, B. 黃布凡. 1991. Qiang yuzhi 㒸语支 [Qiangic]. In Han-Zangyu Gailun《汉 藏语概论》 [An Introduction to Sino-Tibetan Languages], edited by X. Ma 马学 良，pp. 208-369. Peking University Press 北京大学出版社，Beijing.

Huang, B. 黄布凡, S. Xu 许寿椿, J. Chen 陈嘉瑛, and H. Wang 王会银, eds. 1992. Zang-Mian Yuzu Yuyan Cihui 《藏缅语族语言词汇》 [A Tibeto-Burman lexicon]. Zhongyang Minzu Daxue Chubanshe 中央民族大学出版社, Beijing.

Hübotter, F. 1957. Chinesisch-Tibetische Pharmakologie und Rezeptur. Karl F. Haug Verlag, Ulm-Donau.

Jacques, G. 2011. Tonal Alternations in the Pumi Verbal System. Language and Linguistics 12.2:359-392.

Kessler, P. 1986. The Historical Kingdom of Mili. Tibet-Institut Rikon, Laufende Arbeiten zu einem Ethnohistorischen Atlas Tibets (EAT), Zürich.

La, M. 喇明清， S. Tao 陶斯文，W. Hu 胡文明， and W. Cao 曹文山. 2009. Pumizu Jianshi 《普米族简史》 [A brief history of the Pumi]. Minzu Chubanshe 民族出版社, Beijing. 
Li, L. 李蓝. 2010. Sichuan Muli xianfangyan jilue 四川木里县方言计略 [The Chinese dialect of Muli, Sichuan: A survey]. Fangyan 《方言》 [Dialects] 2: 114-133.

Lu, S. 陆绍尊. 2001. Pumiyu Fangyan Yanjiu 《普米语方言研究》 [A Dialectal Study of the Pumǐ Language]. Minzu Chubanshe 民族出版社, Beijing.

Matisoff, J. A. 2003. Handbook of Proto-Tibeto-Burman: System and Philosophy of SinoTibetan Reconstruction. University of California Press, Berkeley.

Muli Gazetteers 1995: Muli Zangzu Zizhixian Zhi Bianzuan Weiyuanhui 木里藏族自治 县志编纂委员会 [Muli Tibetan Autonomous County Gazetteers Editing and Compiling Committee], eds. 1995. Muli Zangzu Zizhixian Zhi 《木里藏族自治 县志》 [Gazetteers of Muli Tibetan Autonomous County]. Sichuan Renmin Chubanshe 四川人民出版社, Chengdu.

Muli Gazetteers 2010: Muli Zangzu Zizhixian Zhi Bianzuan Weiyuanhui 木里藏族自治 县志编纂委员会 [Muli Tibetan Autonomous County Gazetteers Editing and Compiling Committee], eds. 2010. Muli Zangzu Zizhixian Zhi 《木里藏族自治 县志: 1991-2006》 [Gazetteers of Muli Tibetan Autonomous County: 19912006]. Zhongguo Wenshi Chubanshe 中国文史出版社, Beijing.

Myers, N., R. A. Mittermeier, C. G. Mittermeier, G. A. B. da Fonseca, and J. Kent. 2000. Biodiversity Hotspots for Conservation Priorities. Nature 403:853-858.

Oppitz, M., and E. Hsu, eds. 1998. Naxi and Moso Ethnography: Kin Rites and Pictographs. Völkerkundemuseum der Universität Zürich, Zürich.

Qu, A. 篗䨠堂 and X. Jin 金效静. 1981. Zangyu fangyan de yanjiu fangfa 藏语方言 的研究方法 [Methods in the study of the Tibetan dialects]. Xinan Minyuan Xuebao 《西南民院学报》 [Scholarly Journal of the Southwest Institute for Nationalities] 3:76-83.

The Rangjung Yeshe Tibetan-English Dictionary of Buddhist Culture. 2003. Rangjung Yeshe Translations \& Publications, Kathmandu.

Rock, J. F. 1947. The Ancient Na-khi Kingdom of Southwest China. Harvard University Press, Cambridge, Mass.

Sagart, L. 2003. The Vocabulary of Cereal Cultivation and the Phylogeny of East Asian Languages. Indo-Pacific Prehistory Association Bulletin 23:127-136.

Sagart, L., R. Blench, and A. Sanchez-Mazas, eds. 2005. The Peopling of East Asia: Putting Together Archaeology, Linguistics, and Genetics. Routledge Curzon, London and New York.

Sagart, L., and S. Xu. 2001. History through Loanwords: The Loan Correspondences between Hani and Chinese. Cahiers de Linguistique - Asie Orientale 30.1:3-54.

Schneider, E. W. 2007. Postcolonial English, Varieties Around the World. Cambridge University Press, Cambridge.

Sun, H. 孙宏开. 2001. Lun Zang-Mian yuzu zhong de Qiang yuzhi yuyan 论藏缅语族 中的差语支语言 [On the Qiangic branch of the Tibet-Burman language family]. Language and Linguistics 2.1:157-181. 
Wang, X. P., Z. H. Yang, J. S. Hong, I. Kunio, Y. S. Kim, A. C. Hamilton, and S. D. Davis. 1995. Regional overview: China and East Asia. In Centers of Plant Diversity, edited by S.D. Davis, V.H. Heywood and A.C. Hamilton, vol. 2, pp. 145-200. Information Press, Oxford.

Warman, A. 2003. Corn and Capitalism: How a Botanical Bastard Grew to Global Dominance. (Translated by Nancy L. Westrate). The University of North Carolina Press, Chappell Hill and London.

Weckerle, C. S., F. K. Huber, Y. Yang, and W. Sun. 2005a. Walnuts among the Shuhi in Shuiluo, eastern Himalayas. Economic Botany 59.3:287-295.

Weckerle, C. S., F. K. Huber, Y. Yang and W. Sun. 2005b. The Role of Barley among the Shuhi in the Tibetan Cultural Area of the Eastern Himalayas. Economic Botany 59.4:386-390.

Weckerle, C. S., F. K. Huber, Y. Yang, and W. Sun. 2006. Plant Knowledge of the Shuhi in the Hengduan Mountains, Southwest China. Economic Botany 60.1:3-23.

Wellens, K. 2010. Religious Revival in the Tibetan Borderlands: The Premi of Southwest China. University of Washington Press, Seattle and London.

Wylie, T. 1959. A standard system of Tibetan transcription. Harvard Journal of Asiatic Studies 22:261-267.

Yang F. 杨福泉. 2006. “Namuyi” yu “Na” zhi zuqun guanxi kaolue “纳木依”与“纳”之 族群关系考略 [The ethnic relationship between the Namuyi and Na]. Minzu Yanjiu 《民族研究》 [Minority Studies] 3:52-59. 